\title{
Planktonic production and carbon transfer efficiency along a north-south gradient in the Baltic Sea
}

\author{
Kristin Dahlgren ${ }^{1,2, *}$, Agneta Andersson ${ }^{1,2}$, Ulf Larsson ${ }^{3}$, Susanna Hajdu ${ }^{3}$, \\ Ulf Båmstedt ${ }^{1,2}$ \\ ${ }^{1}$ Department of Ecology and Environmental Sciences, Umeå University, 90187 Umeå, Sweden \\ ${ }^{2}$ Umeå Marine Sciences Centre, 91020 Hörnefors, Sweden \\ ${ }^{3}$ Department of Systems Ecology, Stockholm University, 10691 Stockholm, Sweden
}

\begin{abstract}
A 1 yr study was conducted along a brackish-water production gradient to enhance the understanding of factors governing pelagic food web function. This was achieved by measuring carbon transfer efficiency (TE) from the basal resource to an intermediate trophic level. TE was defined as mesozooplankton carbon consumption rate divided by production at the basal trophic level, which is composed of phytoplankton and bacteria. A north-south transect in the Baltic Sea was used as a model system, with 2 stations each in the Bothnian Bay, Bothnian Sea and Baltic Proper being sampled 5 to $8 \times$ during 2006. In addition, data from monitoring programmes were used, which comprised 10 to 22 samplings $\operatorname{stn}^{-1}$. TE was expected to be governed by the size distribution of phytoplankton and due to the nutrient gradient, we expected to find an optimal cell size, and thus also a high TE, in the intermediate-productive Bothnian Sea. The basal production during summer/autumn increased 5 -fold from north to south, while the mesozooplankton carbon consumption rate exhibited a peak in the Bothnian Sea, being $~ 3 \times$ higher than in both Bothnian Bay and Baltic Proper. TE was found to be intermediate in the Bothnian Bay (average: 0.8), highest in the Bothnian Sea (1.6), and lowest in the Baltic Proper (0.2). We suggest that the variation in carbon transfer efficiency can be explained by the composition of the phytoplankton community, the abundance balance between copepods and cladocerans, as well as the species composition of mesozooplankton in relation to the size structure of phytoplankton.
\end{abstract}

KEY WORDS: Carbon transfer efficiency $\cdot$ Pelagic production $\cdot$ Mesozooplankton $\cdot$ Baltic Sea

\section{INTRODUCTION}

In pelagic systems, bacteria and phytoplankton are the most important basal producers, and the carbon they produce is transferred to higher trophic levels either through the microbial food web or the classical (herbivorous) food web (Legendre \& Rassoulzadegan 1995). Bacteria that make up the base of the microbial food web consume dissolved organic carbon (DOC) that is derived autochthonously from phytoplankton and other planktonic organisms (Azam et al. 1983), or from river runoff as allochthonous dissolved organic carbon, ADOC (Hessen 1985a, Moran \& Hodson 1990). The main predators of bacteria are flagellates and ciliates (Riemann \& Christoffersen 1993, Pace \& Cole
1996). Mesozooplankton (e.g. copepods) cannot utilize organisms smaller than $\sim 3 \mu \mathrm{m}$ (Sherr et al. 1986, Nejstgaard et al. 1995) and are therefore unable to feed directly on bacteria (Wikner \& Hagström 1988). Carbon transfer through the microbial food web from bacteria to mesozooplankton is therefore sustained by intermediate links such as ciliates (Sherr \& Sherr 1984). Phytoplankton, which form the base of the classical food web, produce biomass through the inorganic compound $\mathrm{CO}_{2}$ i some phytoplankton can be consumed directly by mesozooplankton and ciliates. In the classical food web, there is therefore a direct link between basal producers and mesozooplankton.

The relative importance of the 2 pelagic food webs is influenced by nutrient availability; in low-nutrient 
areas, the microbial food web generally dominates, while the classical food web generally dominates in nutrient-rich systems (Legendre \& Rassoulzadegan 1995). Furthermore, there is temporal succession of the 2 food webs in areas where stratification of the water column leads to exhaustion of macronutrients that increase the relative importance of the microbial food web (Sorokin 1981, Cushing 1989). Conversely, the classical food web is important during spring mixing and in upwelling areas where nutrients are constantly replenished.

The carbon transfer efficiency (TE, here defined as the ratio between mesozooplankton carbon consumption rate and basal production) is dependent on the number of trophic levels in the food web. Within and between trophic levels, carbon is lost due to exudation, defecation, sloppy feeding and respiration. In microbial food webs, as compared to classical food webs, increases in the number of trophic levels reduce the amount of carbon reaching higher trophic levels (Sanders \& Wickham 1993, Hessen 1998). However, in highly eutrophic areas, the abundance of relatively inedible filamentous and toxic algae increases, potentially decreasing the food available to mesozooplankton (DeMott et al. 1991, Wolfe \& Steinke 1996), and thereby reducing the TE. Despite the presumed low TE in the microbial food web, this food web is important in many ecosystems, especially when autotrophic production is low compared to allochthonous carbon input, since it provides a functional, albeit inefficient, carbon transfer pathway from basal resources to higher trophic levels (Ackefors et al. 1978, Sherr \& Sherr 1988, Rolff \& Elmgren 2000, Berglund et al. 2007).

There are marked gradients from north to south in a number of important environmental variables in the Baltic Sea. For example, salinity increases from 2-3 in the northern Bothnian Bay to 6-7 in the northern Baltic Proper (Voipio 1981). The most limiting nutrient changes from phosphorus in the north to nitrogen in the south (Graneli et al. 1990, Wulff et al. 1990, Andersson et al. 1996). In the Bothnian Bay, there is a short ice-free period (Andersson et al. 1996), skewed annual insolation with virtually no light during winter and $24 \mathrm{~h}$ of daylight in summer, resulting in a short productive season. This is a low-productive area, with a low autotrophic:heterotrophic ratio (Sandberg et al. 2004, Samuelsson et al. 2006). Furthermore, allochthonous inputs of organic carbon are $\sim 4 \times$ higher $\mathrm{m}^{-2}$ in the Bothnian Bay than in the Bothnian Sea and the Baltic Proper (Elmgren 1984), resulting in a looser relationship between heterotrophic and autotrophic production (Findley et al. 1991, Sandberg et al. 2004). Further south, the ratio between autotrophic and heterotrophic production increases (Ackefors et al. 1978, Sandberg et al. 2004), and is 20 -fold higher in the Baltic Proper than in the Bothnian Bay (Samuelsson et al. 2006). In the more productive Baltic Proper, toxic and filamentous cyanobacteria periodically dominate (Larsson et al. 2001, Hajdu 2002), with potential effects on the energy flow up the food web (DeMott et al. 1991). This shift in composition of the basal resource (phytoplankton + bacteria) from north to south makes this environment useful in examining how TE is affected by the structure of the food web.

The aim of this study was to assess the efficiency of carbon transfer in the planktonic food web up to mesozooplankton in a production gradient and to discuss the main ecological factors governing TE. To assess important ecological factors, biomasses of major organism groups from the 2 food webs were determined, as were species composition of phytoplankton and mesozooplankton. The Baltic Sea with its north-south production gradient was used as a model system. Sampling was performed during all seasons, but conclusions were drawn from the summer/autumn period (Aug-Sep). TE was expected to be low in the Bothnian Bay due to the dominance of small cells in the basal resource (hence, a relatively large number of trophic levels), higher in the Bothnian Sea due to the occurrence of larger cells and thus fewer trophic levels, and again lower in the Baltic Proper due to abundant inedible phytoplankton. We used oxygen consumption as a relative proxy for carbon consumption rate in mesozooplankton. The rationale for this is that oxygen consumption can be converted to carbon utilization by a simple conversion (e.g. Parsons et al. 1977). Moreover, respiration rate is closely correlated with growth rate due to the energy demanding processes of growth (e.g. Kiørboe et al. 1985, Thor 2000).

\section{MATERIALS AND METHODS}

Sampling. The data analysed in this study were collected from 6 monitoring stations along a salinity/ production gradient in the Baltic Sea during 2006: 2 stations each in the Bothnian Bay (A5: 65 $10^{\prime} \mathrm{N}$, $23^{\circ} 14.00^{\prime} \mathrm{E}$, depth $90 \mathrm{~m}$, and A13: $64^{\circ} 42.50^{\prime} \mathrm{N}$, $22^{\circ} 04.00^{\prime} \mathrm{E}$, depth $120 \mathrm{~m}$ ), Bothnian Sea (C3: 62 $39.17^{\prime} \mathrm{N}$, $18^{\circ} 57.14^{\prime} \mathrm{E}$, depth $195 \mathrm{~m}$, and $\mathrm{C} 14: 62^{\circ} 05.55^{\prime} \mathrm{N}$, $18^{\circ} 32.91^{\prime} \mathrm{E}$, depth $85 \mathrm{~m}$ ) and the Baltic Proper (BY31: $58^{\circ} 35.90^{\prime} \mathrm{N}, 18^{\circ} 14.21^{\prime} \mathrm{E}$, depth $459 \mathrm{~m}, \mathrm{H} 4: 58^{\circ} 59.02^{\prime} \mathrm{N}$, $17^{\circ} 43.52^{\prime}$ E, depth $31 \mathrm{~m}$ ) (Fig. 1). Stns A5, A13, C3, C14 and BY31 are off-shore, whereas Stn H4 is a coastal station in a nutrient-enriched bay. On 5 to 8 occasions from February to November, samples were taken to obtain estimates of bacterial production, mesozooplankton carbon consumption rate and biomass of bacteria, protozoa and mesozooplankton from microscopic 


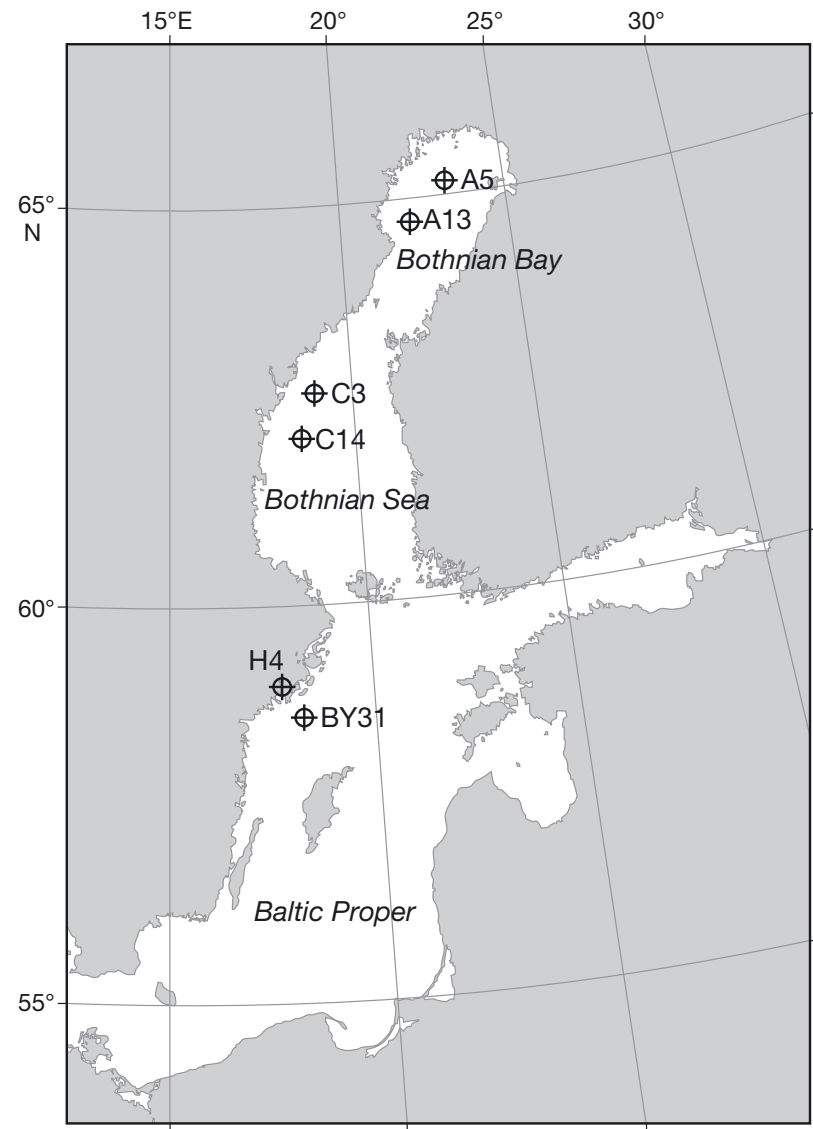

Fig. 1. The Baltic Sea showing locations of the sampling Stns A5 and A13 (Bothnian Bay), C3 and C14 (Bothnian Sea), and BY31 and H4 (Baltic Proper)

counts (Appendix 1). This was in addition to samplings performed as part of the regular monitoring programme (10 to 22 station visits $\mathrm{yr}^{-1}$ ) (Appendix 1). The monitoring programme provided us with data on primary production, bacterial production (Bothnian Bay and Bothnian Sea), phytoplankton species composition and biomass as well as physical and chemical data (Grasshoff et al. 1983, HELCOM 2009). Phytoplankton and bacterial production were measured using conventional isotope techniques (Gargas 1975, Fuhrman \& Azam 1982) and mesozooplankton carbon consumption rate using an oxygen respiration technique. Temperature and salinity were measured using a CTD (SeaBird 911 plus). Nutrients were measured at discrete depths from the surface to the bottom and analysed using an autoanalyzer (TrAAcs/QuAAtro) according to Grasshoff et al. (1983) (Stns A5, A13, C3 and C14) or according to Larsson et al. (2001) (Stns BY31 and $\mathrm{H} 4$ ).

Phytoplankton biomass and production. Phytoplankton species composition and biomass were determined in depth-integrated samples (Stns A13 and C3, 0-10 m; BY31, 0-20 m; H4, 0-14 m; Table 1) at one station each in the Bothnian Bay (A13) and Bothnian Sea (C3) and at both stations in the Baltic Proper (BY31 and H4) at the time of all station visits (Appendix 1). Phytoplankton $(>2 \mu \mathrm{m})$ samples were preserved in acidic Lugol's solution and counted after settling in sedimentation chambers $(10,25$ or $50 \mathrm{ml})$ using an inverted microscope (Nikon Eclipse TE 300/ Wild M40). Half of the settling area was scanned for microplankton (20 to $200 \mu \mathrm{m}$ ) at $100 \times$ magnification and 1 or 2 diagonals were scanned for nanoplankton (2 to $20 \mu \mathrm{m}$ ) at 400× magnification (HELCOM 2009). Picocyanobacteria $(<2 \mu \mathrm{m})$ were counted only 8 to $9 \times$ in the Gulf of Bothnia (Bothnian Bay and Bothnian Sea) and 5 to $6 \times$ in the Baltic Proper. They were analysed from flagellate slides (see below) and counted by autofluorescence with an epifluorescence microscope at $1000 \times$ magnification using green excitation light (510-560 nm, emission wavelength >590 nm). Thirty large $(100 \times 100 \mu \mathrm{m})$ or small $(30 \times 30 \mu \mathrm{m})$ squares were counted for picocyanobacteria. When the cell number exceeded 50 in the large square, the

Table 1. Sampling depth $(\mathrm{m})$ for the different variables at the different stations. BB: bacterial biomass, BP: bacterial production, PB: phytoplankton biomass, Pico: picophytoplankton biomass, PP: phytoplankton primary production, MB: mesozooplankton biomass, $\mathrm{MZ}_{\mathrm{CCR}}$ : mesozooplankton carbon consumption rate, Flag: flagellate biomass, and Cil: ciliate biomass

\begin{tabular}{|c|c|c|c|c|c|c|}
\hline \multirow[t]{2}{*}{ Parameteı } & \multicolumn{2}{|c|}{ Baltic Proper } & \multicolumn{2}{|c|}{-Bothnian Sea } & \multicolumn{2}{|c|}{ - Bothnian Bay } \\
\hline & $\mathrm{H} 4$ & BY31 & C14 & C3 & A13 & A5 \\
\hline $\mathrm{BB}$ & $1,5,10,20,30$ & $1,5,10,40,60,80$ & $1,5,10,40,60,80,85$ & $1,5,10,40,60,190,195$ & $1,5,10,40,60,110,125$ & $1,5,10,40,60,80,95$ \\
\hline $\mathrm{BP}$ & $1,5,10,20,31$ & $1,5,10,40,60,81$ & $1,5,10,40,60,80,86$ & $1,5,10,40,60,190,196$ & $1,5,10,40,60,110,126$ & $1,5,10,40,60,80,96$ \\
\hline PB & $0-14$ & $0-20$ & & $0-10$ & $0-10$ & \\
\hline Pico & $0-10$ & $0-20$ & & $0-10$ & $0-10$ & \\
\hline PP & $0,1,2,3,4,6,8,11,14$ & $0-20$ & $0-10$ & $0-10$ & $0-10$ & $0-10$ \\
\hline MB & $0-\sim 30$ & $0-70(80)$ & $0-\sim 75$ & $0-\sim 185$ & $0-\sim 110$ & $0-\sim 85$ \\
\hline $\mathrm{MZ}_{\mathrm{CCR}}$ & $0-\sim 30$ & $0-70(80)$ & $0-\sim 75$ & $0-\sim 185$ & $0-\sim 110$ & $0-\sim 85$ \\
\hline Flag & $0-10$ & $0-10$ & $0-10$ & $0-10$ & $0-10$ & $0-10$ \\
\hline Cil & $0-10$ & $0-10$ & $0-10$ & $0-10$ & $0-10$ & $0-10$ \\
\hline
\end{tabular}


small square was used (HELCOM 2009). Phytoplankton biovolumes were calculated from cell geometries (Olenina et al. 2006), and expressed as wet weight $\left(\mathrm{mg} \mathrm{m}^{-3}\right)$. To determine differences in phytoplankton size structure between the stations, phytoplankton were divided into 4 size groups: $<2 \mu \mathrm{m}, 2-5 \mu \mathrm{m}$, 5-20 $\mu \mathrm{m}$ and $>20 \mu \mathrm{m}$, and their contributions to total biomass were estimated.

Primary production was estimated by the ${ }^{14} \mathrm{C}$ method (Gargas 1975). Mixed integrated samples from 0 to $10 \mathrm{~m}$ depth in the Gulf of Bothnia (A5, A13, $\mathrm{C} 3$ and $\mathrm{C} 14)$ and from 0 to $20 \mathrm{~m}$ depth in the Baltic Proper (BY31) (Table 1) were incubated in $50 \mathrm{ml}$ bottles with $0.12 \times 10^{6} \mathrm{~Bq}\left(3.7 \times 10^{6} \mathrm{~Bq} \mathrm{mmol}{ }^{-1}\right)$ sodium bicarbonate $\left({ }^{14} \mathrm{C}\right)$ for $3 \mathrm{~h}$ in an incubator at ambient temperature and different artificial light levels (10 fluorescent tubes, mean light intensity of $500 \mu \mathrm{E} \mathrm{m}^{-2} \mathrm{~s}^{-1}$ ). At Stn $\mathrm{H} 4$, discrete samples were incubated in situ in $80 \mathrm{ml}$ polycarbonate bottles with $0.2 \times 10^{6} \mathrm{~Bq}$ sodium bicarbonate $\left({ }^{14} \mathrm{C}\right)$ at sampling depths of $0,1,2,3,4,6$, 8,11 and $14 \mathrm{~m}$ (dark bottles at 0,3 and $14 \mathrm{~m}$ ) (Table 1). To stop ${ }^{14} \mathrm{C}$ uptake, $5 \mathrm{ml}$ of each sample was transferred to $20 \mathrm{ml}$ scintillation bottles and $300 \mu \mathrm{l}$ of $5 \mathrm{M}$ hydrochloric acid was added prior to bubbling with air for $30 \mathrm{~min}$ to remove excess inorganic ${ }^{14} \mathrm{C}$. The samples were analysed in a scintillation counter (Beckman Coulter LS 6500/Packard Tri-Carb 1600 TR) after the addition of $15 \mathrm{ml}$ scintillation fluid. Daily net phytoplankton primary production was estimated from incubation measurements according to HELCOM guidelines (HELCOM 2009) and from in situ measurements according to Larsson et al. (2001). Depth-integrated values were calculated (using trapetz integration) to obtain estimates of production per unit area $\left(\mathrm{m}^{2}\right)$, and daily values were calculated by multiplying production by the ratio between total daily photosynthetically active radiation (PAR) and the PAR during the incubation period (Andersson et al. 1996).

Bacterial biomass and production. Bacterial variables were measured throughout the entire oxygenated water column. Seawater was sampled from 1 , $5,10,40$ and $60 \mathrm{~m}$ at all stations except $\mathrm{H} 4$, where the sampling depths were 1, 5, 10, 20 and $30 \mathrm{~m}$. In addition, 1 or 2 deeper samples were taken from A5, A13, C14, C3 and BY31, depending on the depth at the station (Table 1). Samples for estimating bacterial abundance and biovolume were preserved in $0.2 \mu \mathrm{m}$ filtered formaldehyde to a final concentration of $4 \%$. From each of these samples, 3 to $7 \mathrm{ml}$ was filtered onto $0.2 \mu \mathrm{m}$ black polycarbonate filters and stained with acridine orange (Zimmerman \& Meyer-Reil 1974). Cell numbers and biovolumes were estimated using an epifluorescence microscope (Zeiss Axiovert 100) at 630× magnification, in combination with the image analysis technique described by Blackburn et al. (1998). Carbon biomass ( $\mathrm{pg} \mathrm{C}^{-1}$ ) was estimated using the following formula (Norland 1993):

$$
\text { Carbon biomass }=0.12 \times \mathrm{CV}^{0.7} \times \mathrm{N}_{\mathrm{b}}
$$

where CV is cell volume $\left(\mu m^{3}\right)$ and $N_{b}$ is cell density (cells l-1).

Bacterial net production was measured using the [ ${ }^{3} \mathrm{H}$-methyl]-thymidine incorporation method (Fuhrman \& Azam 1982). One $1.5 \mathrm{ml}$ sample and one control from each depth (Table 1) were incubated with $0.074 \times$ $10^{6} \mathrm{~Bq}\left(2.81 \times 10^{12}\right.$ to $\left.3.07 \times 10^{12} \mathrm{~Bq} \mathrm{mmol}{ }^{-1}\right)$ of $\left[{ }^{3} \mathrm{H}-\right.$ methyl]-thymidine at the in situ temperature for $1 \mathrm{~h}$ (HELCOM 2009). The incubation was stopped by adding $100 \mu \mathrm{l}$ of $50 \%$ TCA (trichloroacetic acid). The samples were then centrifuged and the pellet was washed with $5 \%$ TCA. After adding $1 \mathrm{ml}$ of scintillation fluid, the samples were analysed in a scintillation counter (Beckman Coulter LS 6500/Packard Tri-Carb 1600 TR). Bacterial production at each depth was calculated according to Fuhrman \& Azam (1982), and then depth integrated (trapetz integration) using data for all sampled depths to obtain an estimate of the production per $\mathrm{m}^{2}$ on each sampling occasion at each station.

Mesozooplankton biomass and carbon consumption rate $\left(\mathbf{M Z}_{\mathbf{C C R}}\right)$. Quantitative zooplankton samples were taken vertically with a WP2 net ( $90 \mu \mathrm{m}$ mesh size) from close to the seabed to the surface at each station, except at BY31 where only the oxygenated part of the water column (usually from a depth of 70 or $80 \mathrm{~m}$ to the surface) was sampled (Table 1). Three to four samples containing viable and active animals representing the zooplankton community (i.e. with the relative distribution of different species and stages) were added to pre-filtered (Whatman GF/F) seawater for the determination of respiration rate. One sample of pre-filtered seawater without mesozooplankton was used as a control. The remaining zooplankton sample was preserved in $4 \%$ borax-buffered formaldehyde for analysis of species composition and biomass. The zooplankton material analysed was classified into taxonomic groups according to HELCOM (2009). The preserved zooplankton samples were divided into subsamples using a modified Folsom splitter. At least 500 specimens were counted using a dissecting microscope and the lengths of the first 10 of each species and developmental stage were measured. Included in the 500 were specimens belonging to the zooplankton groups Copepoda and Cladocera. Carbon biomass was estimated from weight-length regressions according to Kankaala \& Johansson (1986) and Postel et al. (2007). The average zooplankton biomass in the seawater was $0.007 \mu \mathrm{g}$ $\mathrm{C} \mathrm{ml}^{-1} \pm 0.002 \mathrm{SE}$ and the average biomass in the respiration chambers was $15 \mu \mathrm{g} \mathrm{C} \mathrm{ml}^{-1} \pm 4.57$. The concentration was thus much higher in the respiration cham- 
bers, but this was obligatory to detect a change in oxygen concentration. The biomass in the water was calculated as the mean for the whole water column since the net was hauled from the bottom to the surface. However, zooplankton biomass concentration was probably higher in the upper part of the water column and therefore less different from that in the respiration chambers.

The respiration rate was monitored continuously in enclosed chambers of $5 \mathrm{ml}$ volume by means of a Fibox 3 fiberoptic oxygen meter (PreSens). This novel method of estimating respiration rate uses an oxygensensitive foil of the PSt3 type, with a measuring range of 0 to $250 \%$ air saturation ( 0 to $22.6 \mathrm{mg} \mathrm{l}^{-1}$ ). The oxygen sensor input/output of the instrument was connected to a 10-channel mechanical multiplexer, which sequentially connected the fiberoptic cable from the instrument to 10 fiberoptic cables, which were in turn attached at the other end to the outside of each incubation chamber by a plastic holder. A $2 \times 2 \mathrm{~mm}$ piece of sensitive foil that was facing the end of the optical cable was glued inside each incubation chamber. In all measurements, a temperature sensor was connected to the Fibox 3 for logging of the water bath temperature (common for all channels). All functions were controlled by specially developed software, and the results were displayed graphically in real time. Respiration measurements were recorded over $3 \mathrm{~h}$ in darkness using a thermostatic water bath at a temperature corresponding to that in situ in the upper water column. The respiration rate was calculated from log-linear regressions of measurements that produced a better fit of the data than a linear regression, for 1 to $3 \mathrm{~h}$ after the start of the incubation. The first hour was excluded because adaptation to the experimental temperature might have caused stress and produced anomalous results. The method that was used to estimate the mesozooplankton carbon consumption rate $\left(\mathrm{MZ}_{\mathrm{CCR}}\right)$ was based on these respiration measurements, a factor to convert oxygen to carbon units $\left(\mathrm{mg} \mathrm{C}=\mathrm{mg} \mathrm{O}_{2} \times 12 / 32\right.$ $\times \mathrm{RQ}$ ), a respiratory quotient of 0.97 (Ikeda et al. 2000), and a mean assimilation efficiency of 0.8 to represent both small (0.85) and large (0.75) zooplankton (Lima et al. 2002), as shown in the formula:

$$
\mathrm{MZ}_{\mathrm{CCR}}\left(\mathrm{mg} \mathrm{C} \mathrm{m}^{-2} \mathrm{~d}^{-1}\right)=\frac{\mathrm{R} \times 12 / 32 \times \mathrm{RQ}}{\mathrm{AE}} \times \frac{\mathrm{B}}{d}
$$

where $\mathrm{R}$ is the carbon-mass specific mesozooplankton respiration rate $\left(\mathrm{mg} \mathrm{O} \mathrm{O}_{2} \mathrm{C}^{-1} \mathrm{~d}^{-1}\right), \mathrm{RQ}$ is the respiration quotient, $\mathrm{AE}$ is the assimilation efficiency, $\mathrm{B}$ is the mesozooplankton biomass $\left(\mathrm{mg} \mathrm{C} \mathrm{m}^{-3}\right)$ and $d$ is sampling depth interval $(\mathrm{m})$. The molar ratio between carbon and oxygen $\left(\mathrm{C}: \mathrm{O}_{2}\right)$ is $12 / 32$. After the respiration measurements were terminated, the samples were preserved in $4 \%$ buffered formaldehyde for subsequent species and biomass determination. The same classification and counting procedure as above was used, except that all individuals were counted and measured.

Protozoan biomass. To improve the resolution of the food web structure, we enumerated protozoa, i.e. ciliates and flagellates, from integrated seawater samples ( 0 to $10 \mathrm{~m}$ depth) from all stations using a plastic hose $(\varnothing 5 \mathrm{~cm})$ (Table 1). Ciliate samples were preserved in $2 \%$ Lugol's solution. Fifty millilitres of each sample were allowed to settle in a sedimentation chamber for 24 to $48 \mathrm{~h}$ and half of the area of the chamber was counted at $200 \times$ magnification (e.g. Berglund et al. 2007). Biomass was calculated according to species and geometry and by using the carbon conversion factor presented by Menden-Deuer \& Lessard (2000). Flagellate samples were preserved in $1 \%$ glutaraldehyde. From each sample, $15 \mathrm{ml}$ was filtered onto $0.6 \mu \mathrm{m}$ black polycarbonate filters and stained with DAPI (Sherr et al. 1992). One diagonal of the filter was counted in UV light at $1000 \times$ magnification using a Nikon TE 200 epifluorescence microscope. Flagellate biomass was calculated according to their geometry and by using the carbon conversion factor presented by Menden-Deuer \& Lessard (2000).

Carbon transfer efficiency. TE, which is defined as the ratio between mesozooplankton carbon consumption rate (see Eq. 2) and basal production, was calculated using the formula:

$$
\mathrm{TE}=\frac{\mathrm{MZ}_{\mathrm{CCR}}}{\mathrm{PP}+\mathrm{BP}}
$$

Mesozooplankton carbon consumption rate $\left(\mathrm{MZ}_{\mathrm{CCR}}\right)$, net phytoplankton primary production (PP) and net bacterial production (BP) data are all presented in $\mathrm{mg}$ $\mathrm{C} \mathrm{m}^{-2} \mathrm{~d}^{-1}$.

Statistical analyses. Since seasonal development in the different basins varies considerably because of environmental factors, and the sampling frequency was too low to calculate annual estimates, only data from the summer/autumn months (August and September) were used to test for differences between basins. During this period, all stations were sampled once per month. The 2 stations in each basin were treated as replicates, as were the 2 sampling occasions. Differences between basins in terms of biomass, production, carbon consumption rate and TE were tested using the Kruskal-Wallis nonparametric test (K-W) and Mann-Whitney $U$-test (MW) in SPSS 15.0 for MS Windows. We also examined whether the relative proportions of the different phytoplankton size classes differed between Stns A13, C3, BY31 and H4, where phytoplankton biomass was measured. This was also tested for August and September using Kruskal-Wallis nonparametric and Mann-Whitney $U$-tests. All proportions were arcsin transformed before running the tests, and differences between means were deemed significant if $\mathrm{p}<0.05$. 
Table 2. Temperature $\left(\mathrm{T},{ }^{\circ} \mathrm{C}\right)$ and salinity $(\mathrm{S})$ above and below the thermocline and halocline, respectively. Numbers represent minimum and maximum values over the course of the year 2006. Bothnian Bay: A5 and A13, Bothnian Sea: C3 and C14, Baltic Proper: BY31 and H4

\begin{tabular}{|lcccccc|}
\hline Station & $\begin{array}{c}\sim \text { Depth of } \\
\text { thermocline }(\mathrm{m})\end{array}$ & $\begin{array}{c}\text { T above } \\
\text { thermocline }\end{array}$ & $\begin{array}{c}\text { T below } \\
\text { thermocline }\end{array}$ & $\begin{array}{c}\sim \text { Depth of } \\
\text { halocline }(\mathrm{m})\end{array}$ & $\begin{array}{c}\text { S above } \\
\text { halocline }\end{array}$ & $\begin{array}{c}\text { S below } \\
\text { halocline }\end{array}$ \\
\hline A5 & $10-20$ & $-0.14-17.00$ & $0.03-4.84$ & $10-60$ & $2.59-3.17$ & $2.99-3.62$ \\
A13 & $10-40$ & $-0.13-17.04$ & $0.23-3.88$ & $40-60$ & $2.89-3.24$ & $3.13-4.01$ \\
C3 & $10-20$ & $0.75-19.35$ & $0.20-4.01$ & $10-40$ & $4.34-5.32$ & $5.29-6.33$ \\
C14 & $10-20$ & $0.99-18.65$ & $0.64-4.15$ & $40-60$ & $4.72-5.53$ & $5.67-6.16$ \\
BY31 & $15-25$ & $0.39-21.11$ & $1.75-5.94$ & $50-70$ & $6.06-9.60$ & $7.78-11.17$ \\
H4 & $10-15$ & $-0.15-21.30$ & $0.29-11.99$ & $10-15$ & $5.21-6.44$ & $5.73-6.66$ \\
\hline
\end{tabular}

\section{RESULTS}

\section{Hydrography and nutrients}

Surface temperatures started to increase in May in the Gulf of Bothnia and in April in the Baltic Proper, with summer temperatures reaching maxima of $\sim 17^{\circ} \mathrm{C}$ in the Bothnian Bay (Aug-Sep), nearly $20^{\circ} \mathrm{C}$ in the Bothnian Sea (Aug-Sep) and $>20^{\circ} \mathrm{C}$ in the Baltic Proper (early August) (Table 2). Thermoclines were present at the stations in the Bothnian Bay from June to September and in the Bothnian Sea stations from May to September, and were especially strong in August and September, particularly in the Bothnian Sea at depths of $\sim 10$ to $20 \mathrm{~m}$. In November and December, the water column was vertically well mixed. The deepest station, BY31, had a thermocline between 15 and $25 \mathrm{~m}$ from May to October; this was especially pronounced between mid-July and September. The shallowest station, H4, had a thermocline from late April to October, which was most pronounced in July and August.

Surface salinity increased from north to south, ranging from 2.5-3.5 at the northernmost stations in the Bothnian Bay, to $\sim 5$ in the Bothnian Sea and $\sim 6-7$ in the Baltic Proper. There were weak haloclines between May and September at the Bothnian Bay stations, and somewhat stronger haloclines that were most pronounced between April and September at the Bothnian Sea stations. At Stn BY31 in the Baltic Proper, there was a pronounced, permanent halocline at depths of $\sim 70 \mathrm{~m}$ in winter and $\sim 50-60 \mathrm{~m}$ in summer. There was no halocline at Stn H4, but salinity was variable in both surface and deep waters (Table 2).

Total nitrogen concentrations were relatively stable through the year at all stations. The highest values were found at Stn H4, while those of the other stations were similar (Table 3). There were strong latitudinal differences in total phosphorus concentrations, which where lowest in the Bothnian Bay, intermediate in the Bothnian Sea and highest in the Baltic Proper (Table 3). The seasonal variations in total phosphorus levels were relatively low in the Gulf of Bothnia, but the summer values dropped to approximately half the of winter values in the Baltic Proper.

\section{Phytoplankton biomass and primary production (PP)}

The magnitude of the spring bloom increased $\sim 13 \times$ from north to south. The spring bloom occurred in May in the Bothnian Bay and in April in the other 2 basins, and was dominated by the $>20 \mu \mathrm{m}$ size fraction (Fig. 2). Bacillariophyceae, Dinophyceae and autotrophic ciliates were the dominant phytoplankton groups during the bloom (Fig. 3). After the spring bloom, the phytoplankton biomass stabilized below 200, 400 and 600 $\mathrm{mg} \mathrm{m}^{-3}$ in the Bothnian Bay, Bothnian Sea and Baltic Proper, respectively. The $>20 \mu \mathrm{m}$ size class dominated at all stations throughout the year, except between August and December in the Bothnian Bay, when the 5-20 $\mu \mathrm{m}$ size class dominated (Fig. 2). The dominant phytoplankton groups after the spring bloom were Bacillariophyceae, Dinophyceae, autotrophic ciliates (all stations), Cryptophyceae (Stn A13) and Cyanophyceae (Stns C3, BY31 and H4) (Fig. 3). Filamentous

Table 3. Total nitrogen and phosphorus $(\mu \mathrm{M})$ in surface $(0-1 \mathrm{~m})$ and bottom waters. Numbers represent minimum and maximum values over the course of the year 2006. Bothnian Bay: A5 and A13, Bothnian Sea: C3 and C14, Baltic Proper: BY31 and H4

\begin{tabular}{|lrcccc|}
\hline Station & $\begin{array}{c}\text { Depth } \\
(\mathrm{m})\end{array}$ & $\begin{array}{c}\text { Total N } \\
\text { (surface) }\end{array}$ & $\begin{array}{c}\text { Total N } \\
\text { (bottom) }\end{array}$ & $\begin{array}{c}\text { Total P } \\
\text { (surface) }\end{array}$ & $\begin{array}{c}\text { Total P } \\
\text { (bottom) }\end{array}$ \\
\hline A5 & 90 & $15.8-20.8$ & $19.2-23.3$ & $0.10-0.21$ & $0.09-0.24$ \\
A13 & 120 & $15.1-21.9$ & $19.4-22.0$ & $0.12-0.20$ & $0.17-0.43$ \\
C3 & 195 & $14.1-20.9$ & $19.1-22.8$ & $0.20-0.55$ & $0.99-1.16$ \\
C14 & 85 & $13.0-19.1$ & $19.3-26.8$ & $0.25-0.61$ & $0.88-1.46$ \\
BY31 & 459 & $19.1-21.3$ & $17.3-21.6$ & $0.40-0.84$ & $3.75-4.06$ \\
H4 & 30 & $25.2-41.8$ & $20.8-31.6$ & $0.63-1.99$ & $1.17-2.90$ \\
\hline
\end{tabular}




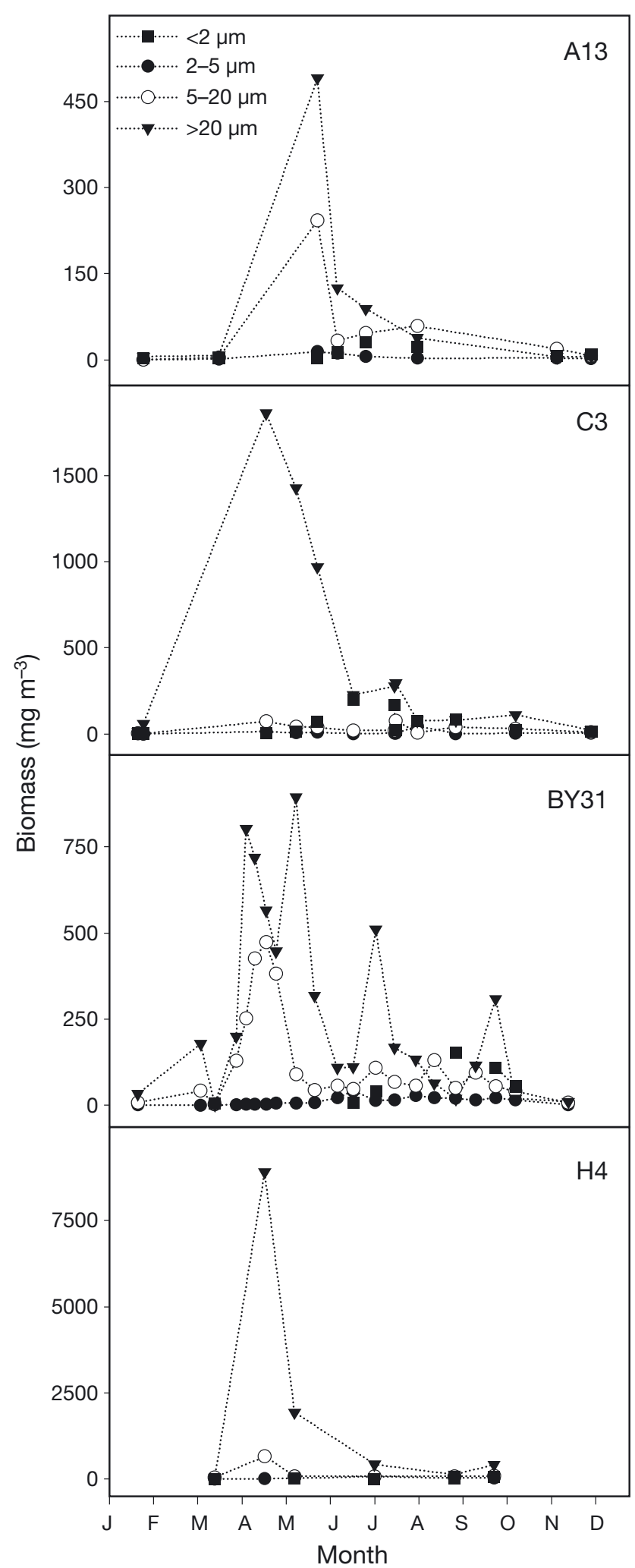

Fig. 2. Biomass $\left(\mathrm{mg} \mathrm{m}^{-3}\right)$ distribution of different size-groups of phytoplankton $(<2,2-5,5-20$ and $>20 \mu \mathrm{m})$ at Stns A13 (Bothnian Bay), C3 (Bothnian Sea), BY31 and H4 (Baltic Proper). Note the different scales on the $y$-axis
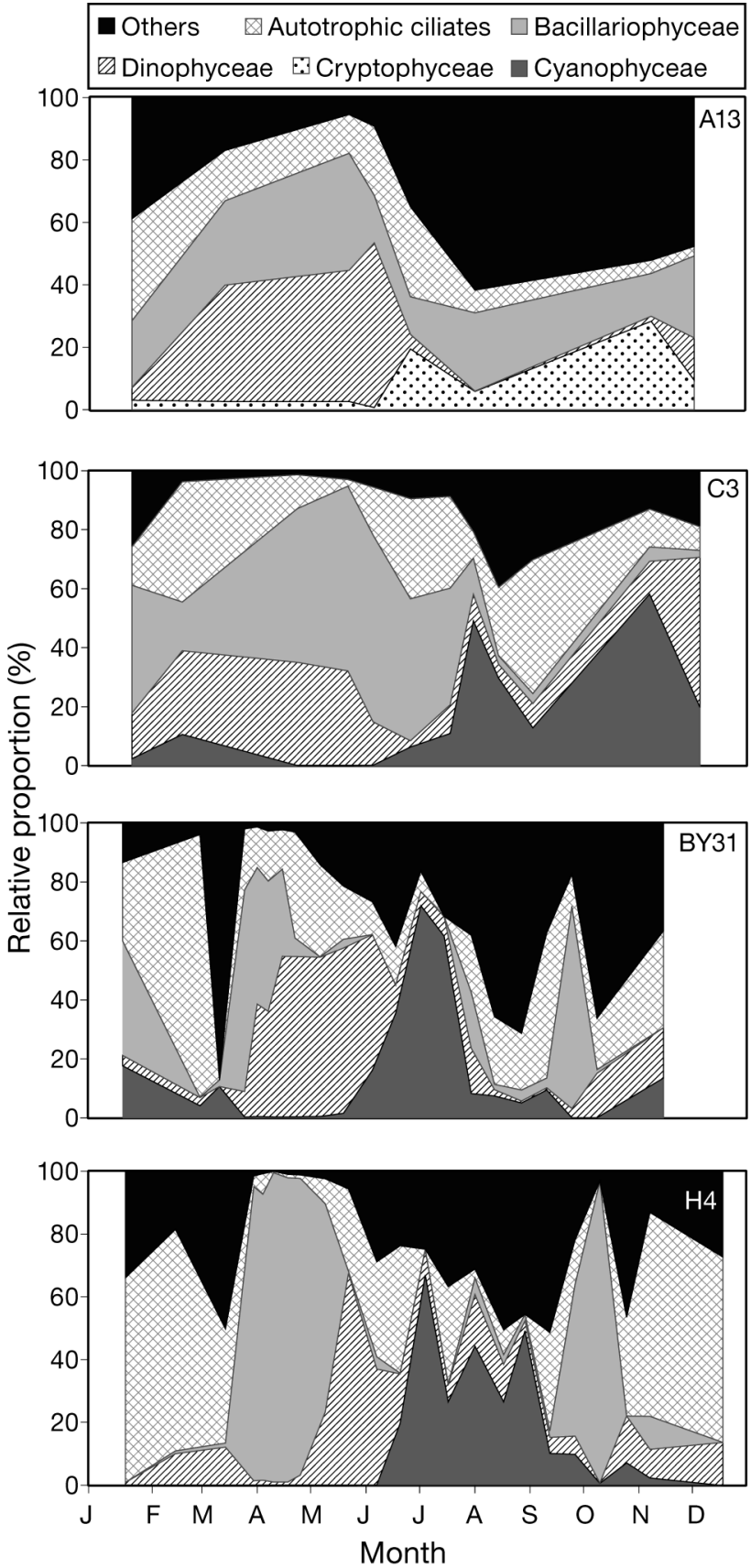

Fig. 3. Relative proportion (\%) of the dominant phytoplankton groups at Stns A13 (Bothnian Bay), C3 (Bothnian Sea), BY31 and H4 (Baltic Proper). 'Others' include nanoplankton species $<20 \mu \mathrm{m}$ (belonging to Cryptophyceae, Chrysophyceae, Euglenophyceae, Prymnesiophyceae, Chlorophyceae, Prasinophyceae, and unidentified nanoflagellates)

cyanobacteria increased in abundance in June to July at both stations in the Baltic Proper, constituting up to 71 and $66 \%$ of the total biomass in early July at Stns BY31 and H4, respectively. At Stn C3, this group dominated in November (Fig. 3). During August to September, total biomass of phytoplankton was 203, 360 and 
$560 \mathrm{mg} \mathrm{m}^{-3}$ in the Bothnian Bay, Bothnian Sea and Baltic Proper, respectively. No significant difference was found between the relative proportions of the different size classes or in total biomass during August to September ( $p>0.05, K-W$ test).

PP averaged over the year increased $\sim 1.2$-fold from the Bothnian Bay to the Bothnian Sea and another $\sim 8$-fold in the Baltic Proper (Fig. 4). During August to September, average PP was 77, 76 and $680 \mathrm{mg} \mathrm{C} \mathrm{m}^{-2}$ $\mathrm{d}^{-1}$ in the Bothnian Bay, Bothnian Sea and Baltic Proper, respectively, with PP being significantly higher in the Baltic Proper than in the Bothnian Bay and Bothnian Sea ( $p<0.05$, K-W with $M-W$ test).

\section{Bacterial biomass and production (BP)}

Bacterial biomass at the Bothnian Bay and Bothnian Sea stations was relatively stable throughout the year (Fig. 5). At the BY31 and H4 stations in the Baltic Proper, bacterial biomass was relatively low during spring and early summer, but increased in late summer and autumn (Fig. 5). During August to September, average biomass was 18, 21 and $142 \mathrm{mg} \mathrm{C} \mathrm{m}^{-3}$ in the Bothnian Bay, Bothnian Sea and Baltic Proper, respectively, with biomass in the Baltic Proper being significantly higher than that in the other 2 basins $(p<0.05$, $\mathrm{K}-\mathrm{W}$ with $\mathrm{M}-\mathrm{W}$ test).

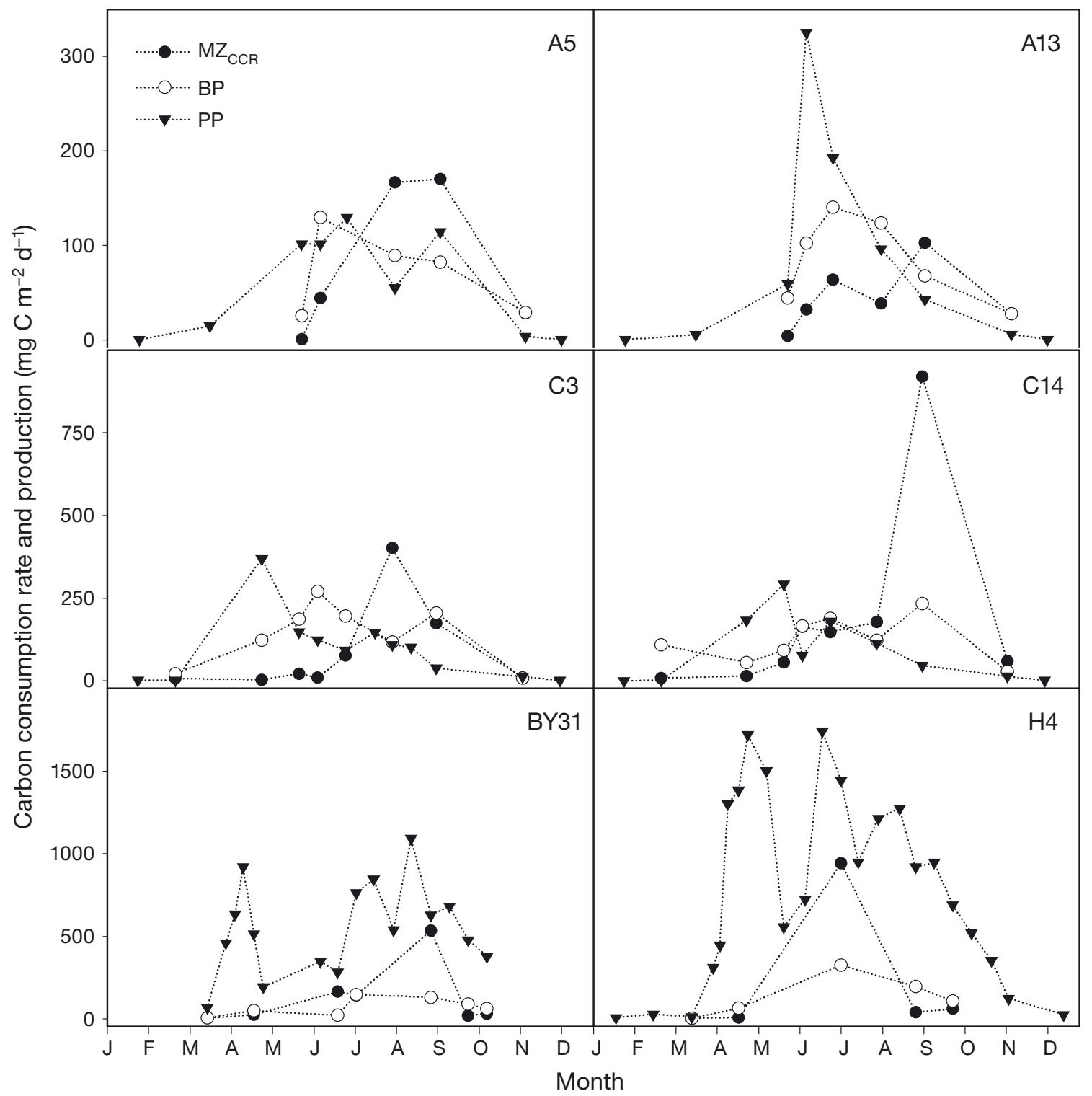

Fig. 4. Mesozooplankton carbon consumption rate $\left(\mathrm{MZ}_{\mathrm{CCR}}\right)$, and bacterial and phytoplankton primary production (BP, $\left.\mathrm{PP}\right)$ (mg C $\mathrm{m}^{-2} \mathrm{~d}^{-1}$ ) from February to November 2006. A5 and A13 (Bothnian Bay); C3 and C14 (Bothnian Sea); BY31 and H4 (Baltic Proper). Note the different scales on the $y$-axis 
BP was low during winter and highest during the summer months (Fig. 4). Average production was highest in the Bothnian Sea, and was $~ 1.7$-fold higher than in the Bothnian Bay and 1.3-fold higher than in the Baltic Proper. A single distinct production peak occurred at the 2 stations in the Bothnian Bay (A5, May and A13, June), while BP peaks occurred in May and September at Stns C3 and C14 in the Bothnian Sea. BP was comparatively low throughout the year at Stn BY31 in the Baltic Proper. There was no distinct peak at Stn H4, although BP increased during the summer months (Fig. 4). No significant differences in BP were found between the basins in August and September, with average production being 91, 169 and $131 \mathrm{mg} \mathrm{C}$ $\mathrm{m}^{-2} \mathrm{~d}^{-1}$ in the Bothnian Bay, Bothnian Sea and Baltic Proper, respectively ( $p=0.092, \mathrm{~K}-\mathrm{W}$ with $\mathrm{M}$-W-test).

\section{Basal production $(\mathrm{BP}+\mathrm{PP})$}

The average ratio between phytoplankton and bacterial production increased from 1:1 in the Gulf of Bothnia to $~ 9: 1$ in the Baltic Proper. The total basal production, i.e. the sum of phytoplankton and bacterial production, showed a strong north-south gradient, being lowest in the Bothnian Bay (33 to $428 \mathrm{mg} \mathrm{C} \mathrm{m}^{-2} \mathrm{~d}^{-1}$ ),

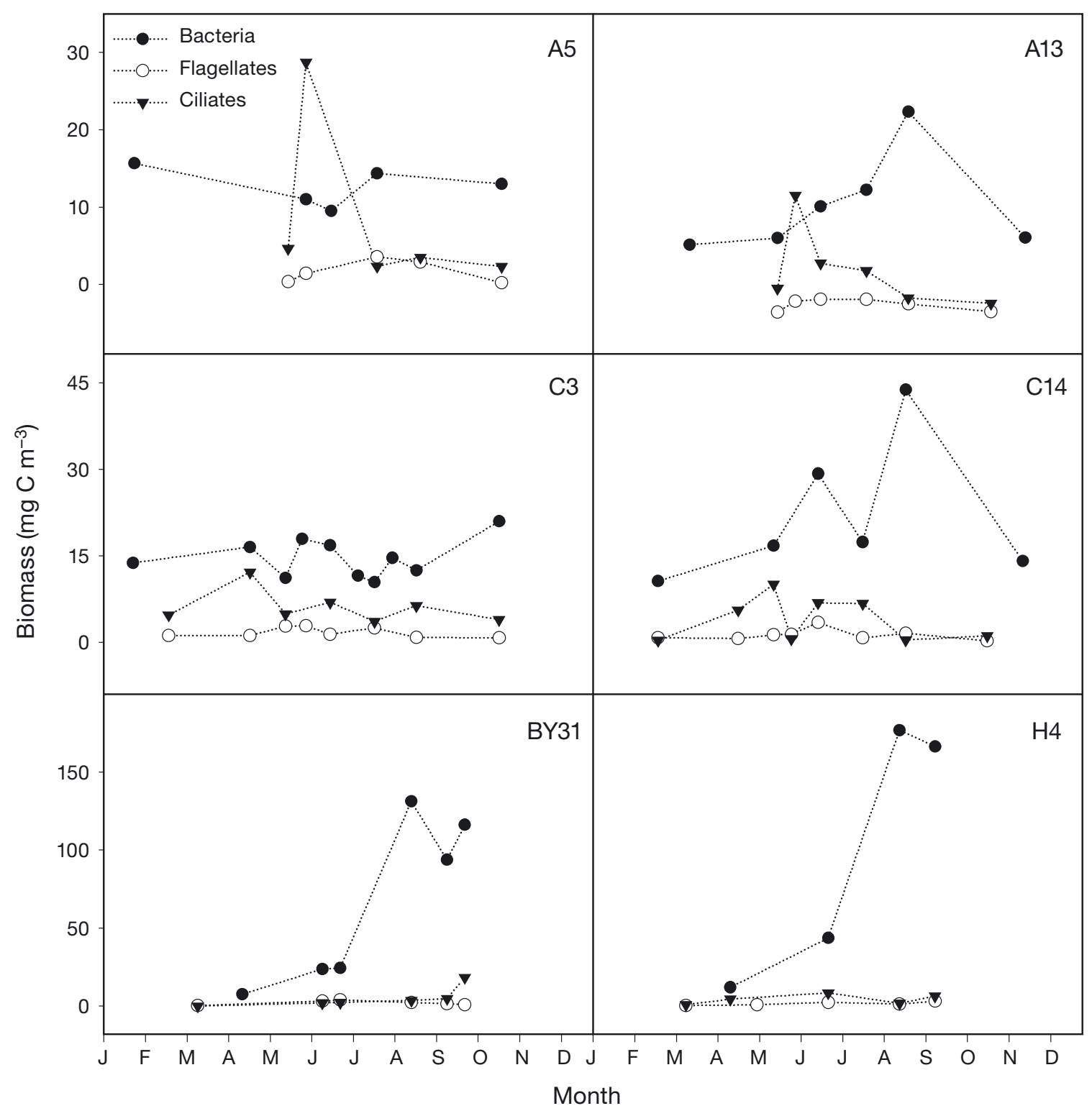

Fig. 5. Bacterial, flagellate and ciliate biomass $\left(\mathrm{mg} \mathrm{C} \mathrm{m}^{-3}\right)$ at each of the stations in the Bothnian Bay (A5 and A13), Bothnian Sea (C3 and C14) and Baltic Proper (BY31 and H4) 
somewhat higher in the Bothnian Sea (20 to $492 \mathrm{mg} \mathrm{C}$ $\mathrm{m}^{-2} \mathrm{~d}^{-1}$ ) and 2 to $7 \times$ higher in the Baltic Proper (17 to $1657 \mathrm{mg} \mathrm{C} \mathrm{m}^{-2} \mathrm{~d}^{-1}$ ). During August to September, the average basal production was 168, 245 and $811 \mathrm{mg} \mathrm{C}$ $\mathrm{m}^{-2} \mathrm{~d}^{-1}$ in the Bothnian Bay, Bothnian Sea and Baltic Proper, respectively, with differences between all basins being significant ( $\mathrm{p}<0.05, \mathrm{~K}-\mathrm{W}$ with $\mathrm{M}-\mathrm{W}$ test).

\section{Mesozooplankton biomass and carbon consumption rate $\left(\mathrm{MZ}_{\mathrm{CCR}}\right)$}

Mesozooplankton biomass was low during winter and started to increase in April to May, reaching max- imum values between July and September (Fig. 6). Yearly mesozooplankton biomass increased 1.6-fold from the Bothnian Bay to the Bothnian Sea and a further 2.5-fold in the Baltic Proper. Calanoid copepods dominated the mesozooplankton assemblage during most of the year in all basins (Fig. 6). The diversity of calanoid copepods increased from north to south: only 3 different genera (Acartia spp., Eurytemora sp., Limnocalanus sp.) were found in the Bothnian Bay where Limnocalanus sp. (L. macrurus) dominated throughout the year (Fig. 7a). In the Bothnian Sea, 2 additional genera were found, i.e. Temora spp. and Pseudocalanus spp. L. macrurus also dominated during most of the year in this basin, but Eurytemora

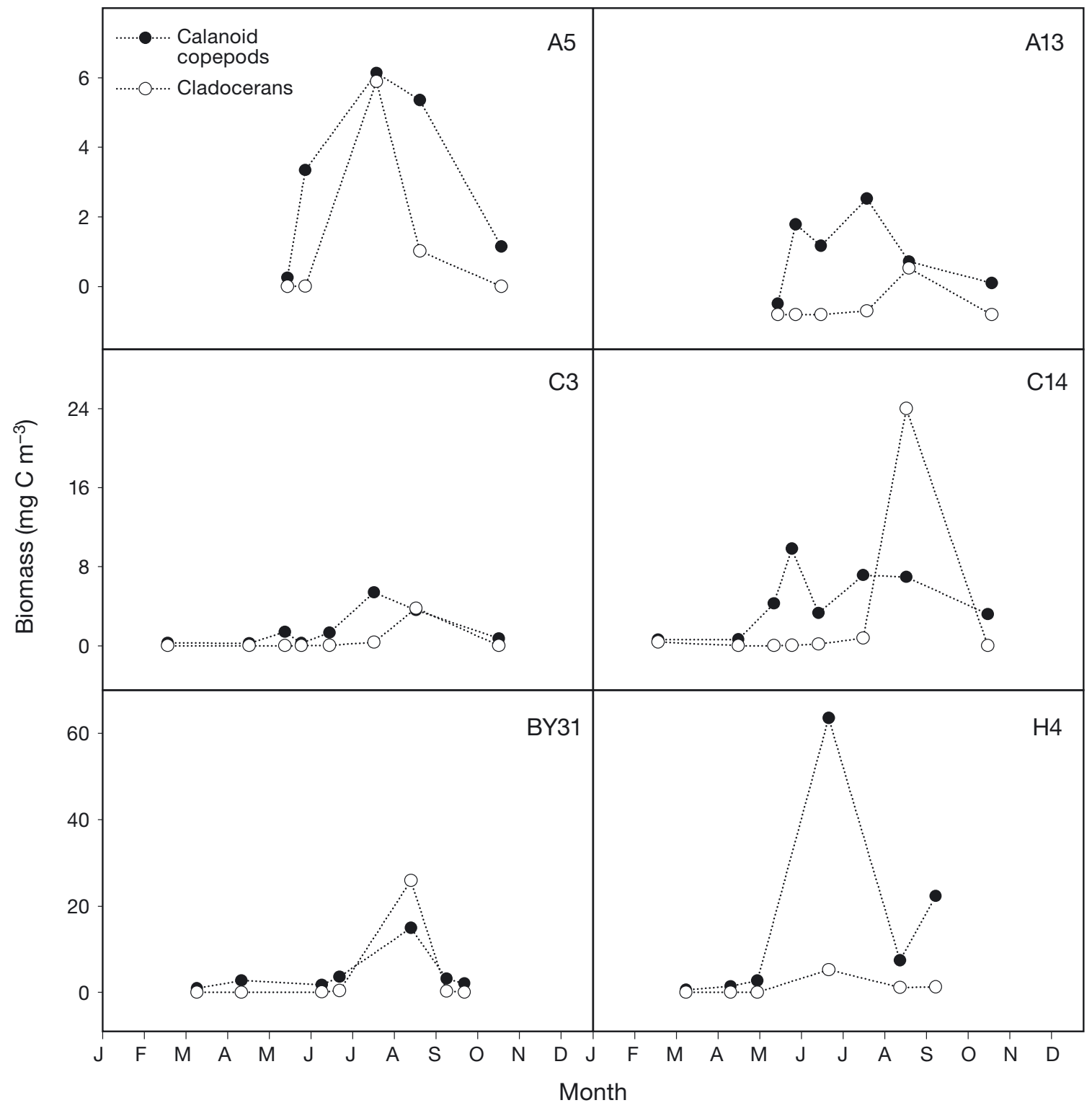

Fig. 6. Mesozooplankton biomass $\left(\mathrm{mg} \mathrm{C} \mathrm{m}^{-3}\right)$, divided into calanoid copepods and cladocerans, at each of the stations in the Bothnian Bay (A5 and A13), Bothnian Sea (C3 and C14) and Baltic Proper (BY31 and H4) 


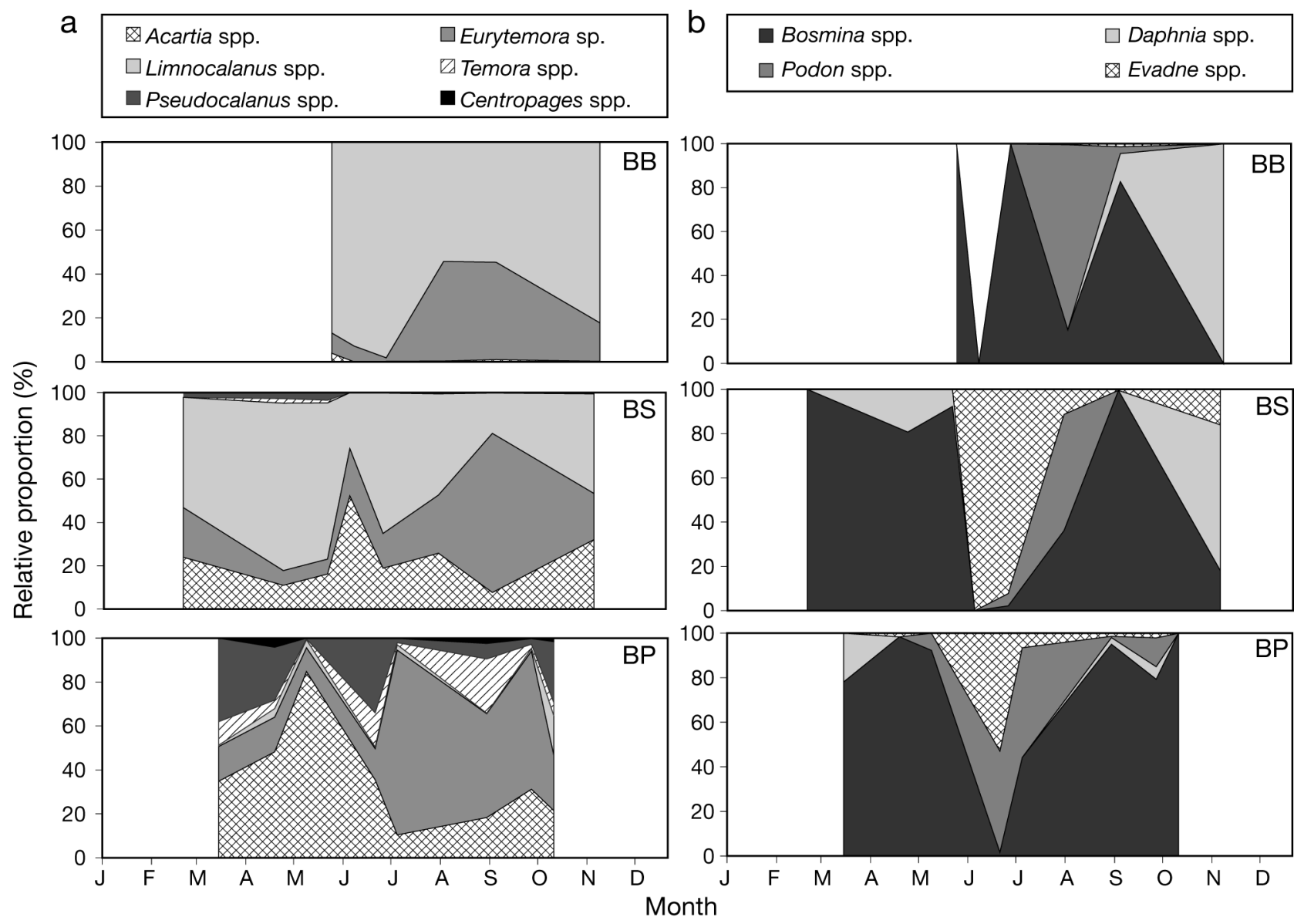

Fig. 7. Relative proportion (\%) of different genera of calanoid copepods (a) and cladocerans (b) in the basins Bothnian Bay (BB), Bothnian Sea (BS) and Baltic Proper (BP)

sp. (E. affinis) was somewhat more dominant in September (Fig. 7a). In addition to the above mentioned genera, the genus Centropages spp. also occurred in the Baltic Proper. During spring and early summer (Mar-Jun), Acartia spp. (A. bifilosa, A. longicornis and A. tonsa) dominated in the Baltic Proper, whereafter $E$. affinis increased in abundance, dominating during the rest of the year (Fig. 7a). Cladocerans were mainly found during late summer when surface temperatures were between 15 and $20^{\circ} \mathrm{C}$ (Fig. 6). They constituted a large fraction of the total biomass at Stns BY31 (63\%) and C14 $(77 \%)$ in August and September when the mesozooplankton biomass was at a seasonal maximum (Fig. 6). Among the cladocerans, Bosmina spp. dominated in all basins (Fig. 7b). The other cladocerans that were observed were Daphnia spp. (occurred during spring and autumn), Podon spp. (mainly abundant during summer and early autumn, June-Sep), and Evadne spp. (dominated in June in the Bothnian Sea and Baltic Proper) (Fig. 7b). No significant difference in mesozooplankton biomass was found between the basins during August to September ( $p=0.276$, K-W test) when average mesozooplankton biomass was 6 ,
13 and $19 \mathrm{mg} \mathrm{C} \mathrm{m}^{-3}$ in the Bothnian Bay, Bothnian Sea and Baltic Proper, respectively.

The carbon consumption rate $\left(\mathrm{mg} \mathrm{C} \mathrm{m} \mathrm{m}^{-2} \mathrm{~d}^{-1}\right.$ ) followed the same pattern as the mesozooplankton biomass, i.e. it was low during winter (Nov-Mar) at all stations and increased towards late summer (Fig. 4). The average mesozooplankton carbon consumption rate was highest in the Bothnian Sea: 1.3-fold higher than in the Bothnian Bay and 3.1-fold higher than in the Baltic Proper. During August to September, average $\mathrm{MZ}_{\mathrm{CCR}}$ was 119,418 and $164 \mathrm{mg} \mathrm{C} \mathrm{m}^{-2} \mathrm{~d}^{-1}$ in the Bothnian Bay, Bothnian Sea and Baltic Proper, respectively (Fig. 4). No significant differences in $\mathrm{MZ}_{\mathrm{CCR}}$ were found between basins during this time period $(\mathrm{p}=$ $0.087, \mathrm{~K}-\mathrm{W}$ test).

\section{Protozoan biomass}

In the Bothnian Bay, ciliate biomass was rather low at all sampling times except in June (Fig. 5). In the Bothnian Sea, the biomass was generally higher and peaked early, in April to May. At Stns BY31 and H4 in 
the Baltic Proper, ciliate biomass was comparatively low, except in October at Stn BY31 (Fig. 5). No significant difference in average total biomass was found between the different basins $\left(3.2,4.3\right.$ and $4.2 \mathrm{mg} \mathrm{C} \mathrm{m}^{-3}$ in the Bothnian Bay, Bothnian Sea and Baltic Proper, respectively) in August to September ( $p>0.05, \mathrm{~K}-\mathrm{W}$ test). Flagellate biomass was highest in summer at all stations, and was similar between the different basins (Fig. 5). During August to September, average biomass was 2.4, 1.4 and 2.1 in the Bothnian Bay, Bothnian Sea and Baltic Proper, respectively, and did not differ significantly between the basins ( $\mathrm{p}>0.05, \mathrm{~K}-\mathrm{W}$ test).

\section{Relationship between mesozooplankton carbon consumption rate and basal production - carbon transfer efficiency (TE)}

To assess the spatial and temporal variations in carbon transfer through the pelagic food webs in the Baltic Sea, we calculated the ratio between mesozooplankton carbon consumption rate and basal production, i.e. the TE. In the Gulf of Bothnia (Bothnian Bay and Bothnian Sea), the TE was highest from August to September, whereas it was highest between June and August in the Baltic Proper (Fig. 8). In the Bothnian Bay, Bothnian Sea and Baltic Proper, the TE varied from 0.005 to $1.2,0.005$ to 3.3 and 0.006 to 0.7 , respectively (Fig. 8). During August to September, the average TE was $0.78,1.60$ and 0.21 in the Bothnian Bay, Bothnian Sea and Baltic Proper, respectively. A significant difference was found between the basins during this period ( $p=0.035, K-W$ test): the Bothnian Sea had significantly higher TE than the Baltic Proper ( $p=$ 0.029, M-W test), whereas the differences between the Bothnian Bay and the Baltic Proper and between the Bothnian Bay and the Bothnian Sea were not significant ( $p=0.057$ and 0.686 , respectively; $M-W$ test).

\section{DISCUSSION}

Carbon TE was estimated along a production gradient-from an area of low production (Bothnian Bay) through an area of intermediate production (Bothnian Sea) to an area of high production (Baltic Proper). In accordance with our hypothesis, TE was found to be highest in the Bothnian Sea and lowest in the Baltic Proper.

We expected the phytoplankton size structure to affect mesozooplankton abundance, and thus also the TE. The optimal cell size for high clearance rates has been shown to be in the range of 3 to $17 \mu \mathrm{m}$ ESD (equivalent spherical diameter) for the calanoid copepod Calanus finmarchicus (Nejstgaard et al. 1995). An

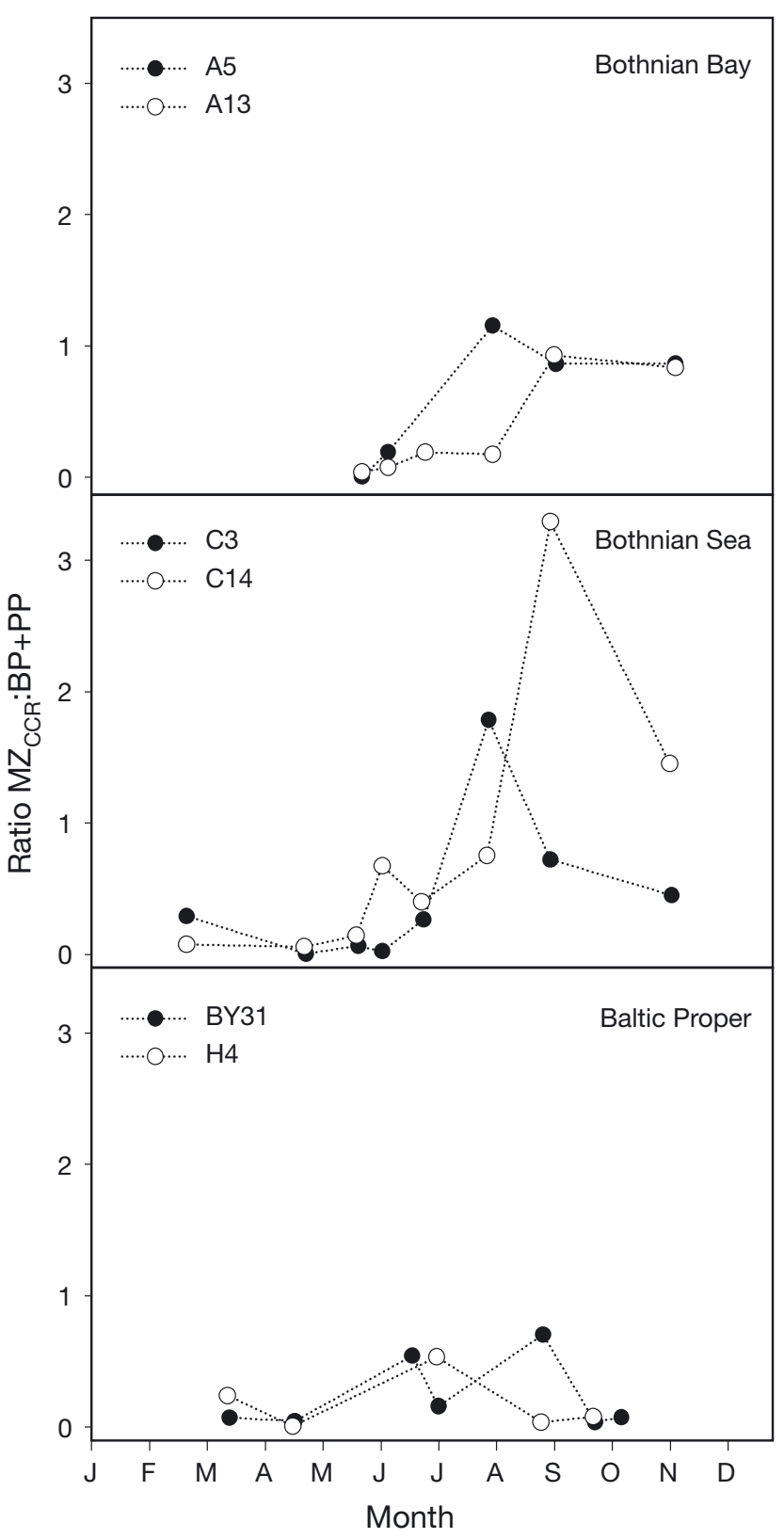

Fig. 8. Carbon transfer efficiency $\left(\mathrm{MZ}_{\mathrm{CCR}}: \mathrm{BP}+\mathrm{PP}\right.$ ratio) at $\mathrm{Stns}$ A5 and A13 (Bothnian Bay), C3 and C14 (Bothnian Sea), and BY31 and H4 (Baltic Proper)

increase in cell size from north to south was expected, based on nutrient (mainly phosphorus) concentrations (Wulff et al. 1990, Legendre \& Rassoulzadegan 1995). In areas with low nutrient concentrations, small algae and bacteria tend to dominate (Legendre \& Rassoulzadegan 1995). In areas with medium to high nutrient concentrations, algae are more likely to be of optimal size, i.e. 3 to $17 \mu \mathrm{m}$, and the food web should therefore be more efficient. In highly nutrient-rich areas, there are often higher numbers of nuisance and 
inedible algae (Wolfe \& Steinke 1996), which may reduce the TE. Accordingly, a peak in TE was noted in the middle basin in this study. However, cells of the optimal size in the phytoplankton community were most abundant in the nutrient poor Bothnian Bay. The 5-20 $\mu \mathrm{m}$ size fraction dominated during autumn at Stn A13. Thus, the relatively high TE in the Bothnian Bay can partly be explained by the abundance of optimally sized phytoplankton cells. However, this does not entirely explain the differences in TE since phytoplankton $>20 \mu \mathrm{m}$ dominated throughout the year in the Bothnian Sea. A possible explanation is that although the phytoplankton community was dominated by cells $>20 \mu \mathrm{m}$, these served as food for the mesozooplankton in this basin. The largest calanoid copepod in the Baltic Sea (Limnocalanus macrurus) was dominant in this basin, and is known to feed on larger phytoplankton (Warren 1985). This species was not as abundant in the Baltic Proper, which could potentially explain some of the difference in TE that was observed between these 2 basins. We further expected the TE to be low in the highly productive Baltic Proper due to the occurrence of inedible algae. Some species of cyanobacteria are toxic and have been shown to negatively affect both the survival and abundance of mesozooplankton (DeMott et al. 1991, Schmidt et al. 2002, Roy et al. 2007). However, other studies have shown that some calanoid copepods are able to feed, survive and reproduce when fed with toxic cyanobacteria (e.g. Nodularia spumigena; Koski et al. 2002, KozlowskySuzuki et al. 2003). Even so, cyanobacteria are a poor quality food source containing low amounts of essential fatty acids (Brett \& Müller-Navarra 1997 and references therein). In accordance with our hypothesis, the lowest TE was indeed found in the Baltic Proper where cyanobacteria were abundant during August and September. However, they were also abundant in the Bothnian Sea, but not until later during autumn. Therefore, during our investigated period (Aug-Sep), cyanobacteria were much more abundant in the Baltic Proper, which potentially caused a reduction in the energy transfer between basal producers and mesozooplankton. Instead of a direct link between phytoplankton and mesozooplankton, the carbon reaches higher trophic levels via the microbial food web by excretion and cell lysis (Sommer et al. 2002). This leads to more trophic levels between the food source and the top predator. We therefore suggest that the phytoplankton size structure as well as the community composition are important factors influencing the TE.

Cladocerans are able to feed on smaller particles (i.e. bacteria) compared to copepods (Nejstgaard et al. 1995, Sommer \& Stibor 2002), and less trophic levels are therefore needed between bacteria and cladocerans than between bacteria and copepods. If cladocer- ans are the dominant mesozooplankton, energy losses from the microbial food web would be lower. Therefore, in areas with a high ratio between heterotrophy and autotrophy, cladocerans are likely to be important for an efficient energy transfer. The ratio between heterotrophy and autotrophy was 1:1 in the Gulf of Bothnia and $\sim 1: 9$ in the Baltic Proper. Cladocerans dominated in the Bothnian Sea during August to September, especially at Stn C14 in September, and also at Stn BY31 in August. Due to the higher ratio of heterotrophs to autotrophs in the Bothnian Sea, cladocerans should be of higher importance for energy transfer in this basin than in the Baltic Proper. This could therefore be one major reason for the high TE observed in the Bothnian Sea. Furthermore, the species composition could also have an impact on the TE. In the area with low production, Limnocalanus macrurus dominated; L. macrurus as well as Eurytemora affinis dominated in the area with intermediate production; and $E$. affinis dominated in the area with high production during August to September. L. macrurus feeds on net phytoplankton, rotifers, as well as nauplii and copepodite stages of cyclopoids and calanoids (Warren 1985). E. affinis, on the other hand, is roughly half the size of L. macrurus and is known to feed on smaller particles such as detritus and small phytoplankton (Heinle \& Flemer 1975, Gulati \& Doornekamp 1991). This could further explain the high TE in the Bothnian Sea where most of the food size spectrum should be readily available for either of the 2 dominant copepods. However, species composition does not explain the relatively high TE in the area with low production or the relatively low TE in the area with high production. According to Work et al. (2005), carbon transfer should be high in areas with large grazers and small phytoplankton and low in areas with small grazers and large phytoplankton. This agrees with our results, with the large copepod L. macrurus and small phytoplankton dominating in the area with low production, and $E$. affinis and large phytoplankton dominating in the area with high production. It therefore seems that both the phytoplankton size spectrum and the mesozooplankton community structure can explain a large part of our observed TE pattern.

Ciliate biomass exhibited a peak in the middle of the transect from north to south, with the highest, albeit insignificant, biomass being found in the Bothnian Sea. In contrast, flagellate biomass showed the opposite trend, with the lowest biomass (again insignificant) being observed in the Bothnian Sea. Thus, the protozoan community does not seem to explain the relative differences in TE between the investigated areas.

In this study, only bottom-up effects were investigated. However, top-down effects are very likely to affect the observed pattern since planktivorous fish 
reduce zooplankton biomass (Möllmann \& Köster 1999). Herring and sprat, which are both planktivores, are the dominant fish species in the Gulf of Bothnia, whereas herring, sprat and cod (a piscivore) dominate in the Baltic proper (ICES 2007). Herring and sprat have a direct influence on zooplankton biomass (Möllmann \& Köster 1999, Köster \& Möllmann 2000), whereas cod should release some of the predation pressure exerted by the planktivores. However, based on total landings, i.e. the total amount (in weight) caught and brought to shore, the only species that are important for the mesozooplankton are the planktivores. The landings of herring and sprat in the Baltic Proper was $\sim 17 \times$ higher $\mathrm{km}^{-3}$ compared to that in the Bothnian Bay and $2 \times$ higher compared to that in the Bothnian Sea (HELCOM 1990, ICES 2007). This suggests that the zooplankton in the Baltic Proper experiences a higher predation pressure (reducing the observed TE) compared to the other basins, especially Bothnian Bay. However, this top-down effect is not as strong as the bottom-up effect. Comparing the Bothnian Sea and the Baltic Proper, basal production increased $4.5 \times$ on average from the former to the latter, whereas the top-down pressure only increased $2 \times$. We therefore argue that although top-down effects were not investigated in this study, it would not influence the major trends in TE.

As already mentioned, a large proportion of the carbon produced by phytoplankton and bacteria is lost from the food web via respiration, sloppy feeding, excretion and export to the benthos. However, some of the excreted carbon can be utilized by bacteria and is thus returned to the food web. Exudation from phytoplankton was not measured in our study; thus, there may be an error in our calculations of TE. To investigate the importance of this potential error, we calculated TE in another way, excluding phytoplankton exudation from the primary production measurements. Larsson \& Hagström (1982) estimated phytoplankton exudation to be $12 \%$ in a eutrophic area and $16 \%$ in a less nutrient rich area. We therefore used the average of these 2 values (14\%) in our calculation. This showed that we might have underestimated the TE by a few percent ( 0 to $12 \%)$, but this should not affect the trends recorded between the basins.

Our data on primary and bacterial production are in agreement with data from earlier studies of the 3 basins (Andersson et al. 1996, Samuelsson et al. 2006, Sandberg 2007). Primary production was measured by the incubation method in all stations, except for Stn H4 where in situ measurements were performed. A $5 \mathrm{yr}$ comparison of incubation and in situ estimates of daily summer (Jun-Aug) primary production in the Baltic Proper (BY31) reveals a nearly systematic underestimation by the incubation method (average $30 \%$, range
41 to $128 \%$ ) (Larsson et al. unpubl.). If these results are applicable to data from the Bothnian Bay and Bothnian Sea, the TE from Stn H4 may have been underestimated relative to those from the other stations. However, increasing the PP by $30 \%$ from all stations except Stn $\mathrm{H} 4$ does not affect our conclusions.

To our knowledge, no previous study has measured the mesozooplankton carbon consumption rate using a similar physiological method. This method of estimating consumption rate does not account for excretion losses or carbon incorporated as growth. The former is a minor factor accounting for $<1 \%$ of the body carbon $\mathrm{d}^{-1}$ (cf. Båmstedt \& Tande 1985), but the latter may be a significant proportion of the carbon consumption rate during certain times of the year. However, since somatic growth is an energy demanding process, variability in the growth rate will also be reflected in the respiration rate (Thor 2000 and references therein). Our method of estimating relative mesozooplankton carbon consumption rate, therefore, reflects real seasonal variations as well as differences between geographical locations with different food conditions. To evaluate the relevance of the results obtained, we compared these with zooplankton production calculated based on mesozooplankton biomass and a temperature-growth relationship (Hirst \& Sheader 1997). The mesozooplankton carbon consumption rate was linearly related to zooplankton production (Aug-Sep: $\mathrm{r}^{2}=0.8551, \mathrm{p}<0.001$, data not shown), indicating that the carbon consumption rate method can be used for studying food web function. Furthermore, both the traditional method of calculating zooplankton production and the measured carbon consumption rate generated similar patterns along the north-south production gradient in the Baltic Sea, indicating that our assessment of pelagic food web function is reliable. The main factor responsible for the close correlation between mesozooplankton carbon consumption rate and zooplankton production is biomass, which is included in both estimates. Our biomass estimates were comparable with those obtained in other studies (Kankaala 1987, Johansson 1997, Huseby \& Wikner 2007).

A wide range of assimilation efficiency (AE) values have been published (32.5 to $92.1 \%$ for mixed zooplankton; Conover 1966). However, since we used a mean value of $\mathrm{AE}$ that represented both small and large zooplankton (Lima et al. 2002), we believe that our estimated TE is reliable.

\section{CONCLUSIONS}

In accordance with our hypothesis, the highest carbon TE was found in the area with intermediate production, while the lowest and intermediate TEs were 
observed in the areas with high and low production, respectively. The main factor that seems to explain this pattern is the mesozooplankton species composition in relation to the size structure of the food particles (mainly phytoplankton), where a high predator volume to prey volume ratio (i.e. large mesozooplankton and small phytoplankton) seems to produce a high TE. Furthermore, in areas where the microbial food web is important, cladocerans seem important in sustaining a high TE. In areas where both the microbial food web and large phytoplankton are important, a wide range of mesozooplankton is favoured, thereby sustaining an efficient carbon transfer up the food web. However, in areas with a high nutrient input from land, the abundance of toxic and filamentous phytoplankton is likely to increase. This affects the feeding response of mesozooplankton, and the carbon instead reaches higher trophic levels through the microbial food web, causing a low TE.

Acknowledgements. This study was supported by grants from the Umeå Marine Sciences Center, the Swedish Research Council for Environment, Agricultural Sciences and Spatial Planning (217-2006-674) and the Kempe Foundation. We thank the personnel at the Umeå and the Stockholm Marine Sciences Centres for technical assistance during field sampling and in the laboratory, and E. Lundberg for technical assistance with the oxygen electrodes. The use of data from the National Swedish Monitoring Programme is gratefully acknowledged.

\section{LITERATURE CITED}

Ackefors H, Hernroth L, Lindahl O, Wulff F (1978) Ecological production studies of the phytoplankton and zooplankton in the Gulf of Bothnia. Finn Mar Res 244:116-126

Andersson A, Hajdu S, Haecky P (1996) Succession and growth limitation of phytoplankton in the Gulf of Bothnia (Baltic Sea). Mar Biol 126:791-801

Azam F, Fenchel T, Field JG, Gray JS, Meyer-Reil LA, Thingstad F (1983) The ecological role of water-column microbes in the sea. Mar Ecol Prog Ser 10:257-263

Båmstedt U, Tande KS (1985) Respiration and excretion rates of Calanus glacialis in arctic waters of the Barents Sea. Mar Biol 87:259-266

Berglund J, Müren U, Båmstedt U, Andersson A (2007) Efficiency of a phytoplankton-based and a bacteria-based food web in a pelagic marine system. Limnol Oceanogr 52: 121-131

Blackburn N, Hagström A, Wikner J, Cuadros-Hansson R, Bjørnsen PK (1998) Rapid determination of bacterial abundance, biovolume, morphology, and growth by neural network-based image analysis. Appl Environ Microbiol 64:3246-3255

Brett MT, Müller-Navarra DC (1997) The role of highly unsaturated fatty acids in aquatic food processes. Freshw Biol 38:483-499

> Conover RJ (1966) Assimilation of organic matter by zooplankton. Limnol Oceanogr 11:338-345

Cushing DH (1989) A difference in structure between ecosystems in strongly stratified waters and in those that are only weakly stratified. J Plankton Res 11:1-13
DeMott WR, Zhang QX, Carmichael WW (1991) Effects of toxic cyanobacteria and purified toxins on the survival and feeding of a copepod and three species of Daphnia. Limnol Oceanogr 36:1346-1357

Elmgren R (1984) Trophic dynamics in the enclosed brackish Baltic Sea. Rapp P-V Reùn Cons Int Explor Mer 183: 152-169

Findley S, Pace ML, Lints D, Cole JJ, Caraco NF, Peierls B (1991) Weak coupling of bacterial and algal production in a heterotrophic ecosystem: the Hudson River Estuary. Limnol Oceanogr 36:268-278

Fuhrman JA, Azam F (1982) Thymidine incorporation as a measure of heterotrophic bacterioplankton production in marine surface waters: evaluation and field results. Mar Biol 66:109-120

Gargas E (1975) A manual for phytoplankton primary production studies in the Baltic. The Baltic Marine Biologists, Publication No. 2, The Danish Agency of Environmental Protection, Hørsholm

Graneli E, Wallstrom K, Larsson U (1990) Nutrient limitation of primary production in the Baltic Sea area. Ambio 19: 142-151

Grasshoff K, Ehrhardt M, Kremling K (1983) Methods of seawater analysis, 2nd edn. Verlag Chemie, Weinheim, New York

Gulati RD, Doornekamp A (1991) The spring-time abundance and feeding of Eurytemora affinis (Poppe) in VolkerakZoommeer, a newly-created freshwater lake system in the Rhine delta (the Netherlands). Hydrobiol Bull 25:51-60

Hajdu S (2002) Phytoplankton of Baltic environmental gradients: observations on potentially toxic species. $\mathrm{PhD}$ thesis, Stockholm University

Heinle DR, Flemer DA (1975) Carbon requirements of a population of the estuarine copepod Eurytemora affinis. Mar Biol 31:235-247

HELCOM (1990) Second periodic assessment of the state of the marine environment of the Baltic Sea, 1984-1988; background document. Baltic Sea Environ Proc 35b:1-432

HELCOM (2000) Nutrient pollution to the Baltic Sea in 2000. Baltic Sea Environ Proc 100

HELCOM (2009) Manual for marine monitoring in the COMBINE Programme of HELCOM. www.helcom.fi/groups/ monas/CombineManual/en_GB/Contents/

Hessen DO (1985a) The relation between bacterial carbon and dissolved humic compounds in oligotrophic lakes. FEMS Microbiol Lett 31:215-223

Hessen DO (1998) Food webs and carbon cycling in humic lakes. In: Hessen DO, Tranvik L (eds) Aquatic humic substances; ecology and biogeochemistry. Springer-Verlag, Heidelberg, p 285-316

Hirst AG, Sheader M (1997) Are in situ weight-specific growth rates body-size independent in marine copepods? A re-analysis of the global syntheses and a new empirical model. Mar Ecol Prog Ser 154:155-165

Huseby S, Wikner J (2007). Djurplankton visar på stabilt system. In: Viklund K, Tidlund A, Brenner U, Lindblom R (eds) Havet 2007 (The Ocean 2007). Naturvårdsverket, p $51-52$ (in Swedish)

ICES (2007) Report of the Baltic Fisheries Assessment Working Group (WGBFAS), 17-26 April 2007. ICES Headquarters, Copenhagen. ICES CM 2007/ACFM:15

Ikeda T, Torres JJ, Hernández-León S, Geiger SP (2000) Metabolism. In: Harris RP, Wiebe PH, Lenz J, Skjoldal HR, Huntley M (eds) ICES zooplankton methodology manual. Academic Press, San Diego, CA, p 455-532

Johansson S (1997) Djurplankton. In: Elmgren R, Larsson U (eds) Himmerfjärden. Förändringar i ett näringsbelastat 
kustekosystem i Östersjön. (Himmerfjärden. Changes in a nutrient-enriched coastal ecosystem of the Baltic Sea.) Rapport 4565, Naturvårdsverket (SEPA), p 80-86 (in Swedish)

Kankaala P (1987) Structure, dynamics and production of mesozooplankton community in the Bothnian Bay, related to environmental factors. Int Rev Gesamten Hydrobiol 72: 121-146

Kankaala P, Johansson S (1986) The influence of individual variation on length-biomass regressions in three crustacean zooplankton species. J Plankton Res 8:1027-1038

Kiørboe T, Møhlenberg F, Hamburger K (1985) Bioenergetics of the planktonic copepod Acartia tonsa: relationship between feeding, egg production and respiration, and composition of specific dynamic action. Mar Ecol Prog Ser 26:85-97

Koski M, Schmidt K, Engström-Öst J, Viitasalo M, Jónasdóttir S, Repka S, Sivonen K (2002) Calanoid copepods feed and produce eggs in the presence of toxic cyanobacteria Nodularia spumigena. Limnol Oceanogr 47:878-885

> Köster FW, Möllmann C (2000) Trophodynamic control by clupeid predators on recruitment success in Baltic cod? ICES J Mar Sci 57:310-323

Kozlowsky-Suzuki B, Karjalainen M, Lehtiniemi M, Engström-Öst J, Koski M, Carlsson P (2003) Feeding, reproduction and toxin accumulation by the copepods Acartia bifilosa and Eurytemora affinis in the presence of the toxic cyanobacterium Nodularia spumigena. Mar Ecol Prog Ser 249:237-249

Larsson U, Hagström $\AA$ (1982) Fractionated phytoplankton primary production, exudate release and bacterial production in a Baltic eutrophication gradient. Mar Biol 67: $57-70$

Larsson U, Hajdu S, Walve J (2001) Baltic Sea nitrogen fixation estimated from the summer increase in upper mixed layer total nitrogen. Limnol Oceanogr 46:811-820

Legendre L, Rassoulzadegan F (1995) Plankton and nutrient dynamics in marine waters. Ophelia 41:153-172

> Lima ID, Olson DB, Doney SC (2002) Intrinsic dynamics and stability properties of size-structured pelagic ecosystem models. J Plankton Res 24:533-556

Menden-Deuer S, Lessard EJ (2000) Carbon to volume relationships for dinoflagellates, diatoms, and other protist plankton. Limnol Oceanogr 45:569-579

Möllmann C, Köster FW (1999) Food consumption by clupeids in the Central Baltic: evidence for top-down control? ICES J Mar Sci 56:100-113

- Moran MA, Hodson RE (1990) Bacterial production on humic and nonhumic components of dissolved organic carbon. Limnol Oceanogr 35:1744-1756

Nejstgaard JC, Båmstedt U, Bagøien E (1995) Algal constraints on copepod grazing. Growth state, toxicity, cell size, and season as regulating factors. ICES J Mar Sci 52: $347-357$

Norland S (1993) The relationship between biomass and volume of bacteria. In: Kemp PF, Sherr BF, Sherr EB, Cole JJ (eds) Handbook of methods in aquatic ecology. Lewis Publishers, Boca Raton, FL, p 303-306

Olenina I, Hajdu S, Edler L, Andersson A and others (2006) Biovolumes and size-classes of phytoplankton in the Baltic Sea. HELCOM, Baltic Sea Environ Proc 106, p 144, www. helcom.fi/stc/files/Publications/Proceedings/bsep106.pdf

Pace ML, Cole JJ (1996) Regulation of bacteria by resources and predation tested in whole-lake experiments. Limnol Oceanogr 41:1448-1460

Parsons TR, Takahasi M, Hargrave B (1977) Biological oceanographic processes. Pergamon Press, Oxford
Postel L, Simon H, Guiard V (2007) Individual-specific carbon mass determination of zooplankton taxa of the open Baltic Sea basing on length / biomass relationships and conversion factors. Final report (in German). Leibniz Institute for Baltic Sea Res, Warnemünde

Riemann B, Christoffersen K (1993) Microbial trophodynamics in temperate lakes. Mar Microb Food Webs 7:69-100

Rolff C, Elmgren R (2000) Use of riverine organic matter in plankton food webs in the Baltic Sea. Mar Ecol Prog Ser 197:81-101

> Roy S, Bhattacharya S, Das P, Chattopadhyay J (2007) Interaction among non-toxic phytoplankton, toxic phytoplankton and zooplankton: inferences from field observations. J Biol Phys 33:1-17

Samuelsson K, Berglund J, Andersson A (2006) Factors structuring the heterotrophic flagellate and ciliate community along a brackish water primary production gradient. J Plankton Res 28:345-359

Sandberg J (2007) Cross-ecosystem analyses of pelagic food web structure and processes in the Baltic Sea. Ecol Modell 201:243-261

Sandberg J, Andersson A, Johansson S (2004) Pelagic food web structure and carbon budget in the northern Baltic Sea: potential importance of terrigenous carbon. Mar Ecol Prog Ser 268:13-29

Sanders RW, Wickham SA (1993) Planktonic protozoa and metazoa: predation, food quality and population control. Mar Microb Food Webs 7:197-223

> Schmidt K, Koski M, Engström-Öst J, Atkinson A (2002) Development of Baltic Sea zooplankton in the presence of a toxic cyanobacterium: a mesocosm approach. J Plankton Res 24:979-992

Sherr BF, Sherr EB (1984) Role of heterotrophic protozoa in carbon and energy flow in aquatic ecosystems. In: Klug MJ, Reddy CA (eds) Current perspectives in microbial ecology. American Society for Microbiology, Washington, DC, p 412-423

> Sherr E, Sherr B (1988) Role of microbes in pelagic food webs: a revised concept. Limnol Oceanogr 33:1225-1227

Sherr EB, Sherr BF, Paffenhofer G (1986) Phagotrophic protozoa as food for metazoans: a 'missing' link in marine pelagic food webs? Mar Microb Food Webs 1:61-80

Sherr EB, Caron DA, Sherr BF (1992) Staining of heterotrophic protists for visualization via epifluorescence microscopy. In: Kemp PF, Sherr BF, Sherr EB, Cole JJ (eds) Current methods in aquatic microbial ecology. Lewis Publishers, Boca Raton, FL, p 213-227

Sommer U, Stibor H (2002) Copepoda-Cladocera-Tunicata: the role of three major mesozooplankton groups in pelagic food webs. Ecol Res 17:161-174

Sommer U, Stibor H, Katechakis A, Sommer F, Hansen T (2002) Pelagic food web configurations at different levels of nutrient richness and their implications for the ratio fish production:primary production. Hydrobiologia 484:11-20

Sorokin IY (1981) Microheterotrophic organisms in marine ecosystems. In: Longhurst, AR (ed) (1981) Analysis of marine ecosystems. Academic Press, London, p 293-342

Thor P (2000) Relationship between specific dynamic action and protein deposition in calanoid copepods. J Exp Mar Biol Ecol 245:171-182

Voipio A (ed) (1981) The Baltic Sea. Elsevier Oceanography Series 30. Elsevier, Amsterdam

> Warren GJ (1985) Predaceous feeding habits of Limnocalanus macrurus. J Plankton Res 7:537-552

Wikner J, Hagström A (1988) Evidence for a tightly coupled nanoplanktonic predator-prey link regulating the bacterivores in the marine environment. Mar Ecol Prog Ser 50: 
$137-145$

Wolfe GV, Steinke M (1996) Grazing-activated production of dimethyl sulphide (DMS) by two clones of Emiliania huxleyi. Limnol Oceanogr 41:1151-1160

Work K, Havens K, Sharfstein B, East T (2005) How important is bacterial carbon to planktonic grazers in a turbid, sub- tropical lake? J Plankton Res 27:357-372

Wulff F, Stigenbrandt A, Rahm L (1990) Nutrient dynamics of the Baltic Sea. Ambio 19:126-133

Zimmerman R, Meyer-Reil LA (1974) A new method for the fluorescent staining of bacterial populations on membrane filters. Kieler Meeresforsch 30:24-27

Appendix 1. Sampling frequency and biological samples taken at each station. BB: bacterial biomass, BP: bacterial production, PB: phytoplankton biomass, Pico: picophytoplankton biomass, PP: phytoplankton primary production, MB: mesozooplankton biomass, $\mathrm{MZ}_{\mathrm{CCR}}$ : mesozooplankton carbon consumption rate, Flag: flagellate biomass, and Cil: ciliate biomass

\begin{tabular}{|c|c|c|c|c|c|c|c|c|c|}
\hline \multirow{2}{*}{$\begin{array}{l}\text { Stn A5 } \\
\text { Date }\end{array}$} & \multirow[b]{2}{*}{$\mathrm{BB}$} & \multirow[b]{2}{*}{$\mathrm{BP}$} & \multirow[b]{2}{*}{$\mathrm{PB}$} & \multirow{2}{*}{$\overline{\mathrm{PiCO}}$} & amples & \multirow[b]{2}{*}{$\mathrm{MB}$} & \multirow[b]{2}{*}{$\mathrm{MZ}_{\mathrm{CCR}}$} & \multirow[b]{2}{*}{ Flag } & \multirow[b]{2}{*}{ Cil } \\
\hline & & & & & $\mathrm{PP}$ & & & & \\
\hline 2006-01-24 & $\mathrm{x}$ & & & & $\mathrm{x}$ & & & & \\
\hline 2006-03-17 & & & & & $\mathrm{x}$ & & & & \\
\hline 2006-05-25 & & $\mathrm{x}$ & & & $\mathrm{x}$ & $\mathrm{x}$ & $\mathrm{x}$ & $\mathrm{x}$ & $\mathrm{x}$ \\
\hline 2006-06-08 & $\mathrm{x}$ & $\mathrm{x}$ & & & $\mathrm{x}$ & $\mathrm{x}$ & $\mathrm{x}$ & $\mathrm{x}$ & $\mathrm{x}$ \\
\hline 2006-06-28 & $\mathrm{x}$ & & & & $\mathrm{x}$ & & & & \\
\hline 2006-08-03 & $\mathrm{x}$ & $\mathrm{x}$ & & & $\mathrm{x}$ & $\mathrm{x}$ & $\mathrm{x}$ & $\mathrm{x}$ & $\mathrm{x}$ \\
\hline 2006-09-06 & & $\mathrm{x}$ & & & $\mathrm{x}$ & $\mathrm{x}$ & $\mathrm{x}$ & $\mathrm{x}$ & $\mathrm{x}$ \\
\hline 2006-11-09 & $\mathrm{x}$ & $\mathrm{x}$ & & & $\mathrm{x}$ & $\mathrm{x}$ & $\mathrm{x}$ & $\mathrm{x}$ & $\mathrm{x}$ \\
\hline 2006-12-06 & & & & & $\mathrm{x}$ & & & & \\
\hline \multicolumn{10}{|l|}{ Stn A13 } \\
\hline Date & BB & BP & $\mathrm{PB}$ & Pico & PP & $\mathrm{MB}$ & $\mathrm{MZ}_{\mathrm{CCR}}$ & Flag & Cil \\
\hline 2006-01-24 & & & $\mathrm{x}$ & $\mathrm{x}$ & $\mathrm{x}$ & & & & \\
\hline 2006-03-17 & $\mathrm{x}$ & & $\mathrm{x}$ & $\mathrm{x}$ & $\mathrm{x}$ & & & & \\
\hline 2006-05-25 & $\mathrm{x}$ & $\mathrm{x}$ & $\mathrm{x}$ & $\mathrm{x}$ & $\mathrm{x}$ & $\mathrm{x}$ & $\mathrm{x}$ & $\mathrm{x}$ & $\mathrm{x}$ \\
\hline 2006-06-08 & & $\mathrm{x}$ & $\mathrm{x}$ & $\mathrm{x}$ & $\mathrm{x}$ & $\mathrm{x}$ & $\mathrm{x}$ & $\mathrm{x}$ & $\mathrm{x}$ \\
\hline $2006-06-28$ & $\mathrm{x}$ & $\mathrm{x}$ & $\mathrm{x}$ & $\mathrm{x}$ & $\mathrm{x}$ & $\mathrm{x}$ & $\mathrm{x}$ & $\mathrm{x}$ & $\mathrm{x}$ \\
\hline 2006-08-03 & $\mathrm{x}$ & $\mathrm{x}$ & $\mathrm{x}$ & $\mathrm{x}$ & $\mathrm{x}$ & $\mathrm{x}$ & $\mathrm{x}$ & $\mathrm{x}$ & $\mathrm{x}$ \\
\hline 2006-09-06 & $\mathrm{x}$ & $\mathrm{x}$ & & & $\mathrm{x}$ & $\mathrm{x}$ & $\mathrm{x}$ & $\mathrm{x}$ & $\mathrm{x}$ \\
\hline 2006-11-09 & & $\mathrm{x}$ & $\mathrm{x}$ & $\mathrm{x}$ & $\mathrm{x}$ & $\mathrm{x}$ & $\mathrm{x}$ & $\mathrm{x}$ & $\mathrm{x}$ \\
\hline 2006-12-06 & $\mathrm{x}$ & & $\mathrm{x}$ & $\mathrm{x}$ & $\mathrm{x}$ & & & & \\
\hline \multicolumn{10}{|l|}{ Stn C3 } \\
\hline Date & BB & $\mathrm{BP}$ & PB & Pico & $\mathrm{PP}$ & $\mathrm{MB}$ & $\mathrm{MZ}_{\mathrm{CCR}}$ & Flag & Cil \\
\hline 2006-01-23 & $\mathrm{x}$ & & $\mathrm{x}$ & $\mathrm{x}$ & $\mathrm{x}$ & & & & \\
\hline 2006-02-20 & & $\mathrm{x}$ & $\mathrm{x}$ & $\mathrm{x}$ & $\mathrm{x}$ & $\mathrm{x}$ & $\mathrm{x}$ & $\mathrm{x}$ & $\mathrm{x}$ \\
\hline 2006-04-25 & $\mathrm{x}$ & $\mathrm{x}$ & $\mathrm{x}$ & $\mathrm{x}$ & $\mathrm{x}$ & $\mathrm{x}$ & $\mathrm{x}$ & $\mathrm{x}$ & $\mathrm{x}$ \\
\hline 2006-05-23 & $\mathrm{x}$ & $\mathrm{x}$ & $\mathrm{x}$ & $\mathrm{x}$ & $\mathrm{x}$ & $\mathrm{x}$ & $\mathrm{x}$ & $\mathrm{x}$ & $\mathrm{x}$ \\
\hline 2006-06-06 & $\mathrm{x}$ & $\mathrm{x}$ & $\mathrm{x}$ & $\mathrm{x}$ & $\mathrm{x}$ & $\mathrm{x}$ & $\mathrm{x}$ & $\mathrm{x}$ & \\
\hline 2006-06-27 & $\mathrm{x}$ & $\mathrm{x}$ & $\mathrm{x}$ & $\mathrm{x}$ & $\mathrm{x}$ & $\mathrm{x}$ & $\mathrm{x}$ & $\mathrm{x}$ & $\mathrm{x}$ \\
\hline 2006-07-19 & $\mathrm{x}$ & & $\mathrm{x}$ & $\mathrm{x}$ & $\mathrm{x}$ & & & & \\
\hline 2006-08-01 & $\mathrm{x}$ & $\mathrm{x}$ & $\mathrm{x}$ & $\mathrm{x}$ & $\mathrm{x}$ & $\mathrm{x}$ & $\mathrm{x}$ & $\mathrm{x}$ & $\mathrm{x}$ \\
\hline 2006-08-15 & $\mathrm{x}$ & & $\mathrm{x}$ & $\mathrm{x}$ & $\mathrm{x}$ & & & & \\
\hline 2006-09-03 & $\mathrm{x}$ & $\mathrm{x}$ & $\mathrm{x}$ & $\mathrm{x}$ & $\mathrm{x}$ & $\mathrm{x}$ & $\mathrm{x}$ & $\mathrm{x}$ & $\mathrm{x}$ \\
\hline 2006-11-07 & $\mathrm{x}$ & $\mathrm{x}$ & $\mathrm{x}$ & $\mathrm{x}$ & $\mathrm{x}$ & $\mathrm{x}$ & $\mathrm{x}$ & $\mathrm{x}$ & $\mathrm{x}$ \\
\hline 2006-12-05 & & & $\mathrm{x}$ & $\mathrm{x}$ & $\mathrm{x}$ & & & & \\
\hline
\end{tabular}


Appendix 1 (continued)

\begin{tabular}{|c|c|c|c|c|c|c|c|c|c|}
\hline \multirow{2}{*}{$\begin{array}{l}\text { Stn C14 } \\
\text { Date }\end{array}$} & \multirow[b]{2}{*}{$\mathrm{BB}$} & \multirow[b]{2}{*}{$\mathrm{BP}$} & \multirow[b]{2}{*}{$\mathrm{PB}$} & \multirow[b]{2}{*}{ Pico } & \multirow{2}{*}{$\begin{array}{l}\text { Samples } \\
\text { PP }\end{array}$} & \multirow[b]{2}{*}{$\mathrm{MB}$} & \multirow[b]{2}{*}{$\mathrm{MZ}_{\mathrm{CCR}}$} & \multirow[b]{2}{*}{ Flag } & \multirow[b]{2}{*}{$\mathrm{Ci}$} \\
\hline & & & & & & & & & \\
\hline 2006-01-23 & & & & & $\mathrm{x}$ & & & & \\
\hline 2006-02-20 & $\mathrm{x}$ & $\mathrm{x}$ & & & $\mathrm{x}$ & $\mathrm{x}$ & $\mathrm{x}$ & $\mathrm{x}$ & $\mathrm{x}$ \\
\hline 2006-04-24 & & $\mathrm{x}$ & & & $\mathrm{x}$ & $\mathrm{x}$ & $\mathrm{x}$ & $\mathrm{x}$ & $\mathrm{x}$ \\
\hline 2006-05-22 & $\mathrm{x}$ & $\mathrm{x}$ & & & $\mathrm{x}$ & $\mathrm{x}$ & $\mathrm{x}$ & $\mathrm{x}$ & $\mathrm{x}$ \\
\hline 2006-06-05 & & $\mathrm{x}$ & & & $\mathrm{x}$ & $\mathrm{x}$ & $\mathrm{x}$ & $\mathrm{x}$ & $\mathrm{x}$ \\
\hline 2006-06-26 & $\mathrm{x}$ & $\mathrm{x}$ & & & $\mathrm{x}$ & $\mathrm{x}$ & $\mathrm{x}$ & $\mathrm{x}$ & $\mathrm{x}$ \\
\hline \multicolumn{10}{|l|}{ 2006-07-19 } \\
\hline 2006-07-31 & $\mathrm{x}$ & $\mathrm{x}$ & & & $\mathrm{x}$ & $\mathrm{x}$ & $\mathrm{x}$ & $\mathrm{x}$ & $\mathrm{x}$ \\
\hline \multicolumn{10}{|l|}{ 2006-08-15 } \\
\hline 2006-09-03 & $\mathrm{x}$ & $\mathrm{x}$ & & & $\mathrm{x}$ & $\mathrm{x}$ & $\mathrm{x}$ & $\mathrm{x}$ & $\mathrm{x}$ \\
\hline 2006-11-06 & & $\mathrm{x}$ & & & $\mathrm{x}$ & $\mathrm{x}$ & $\mathrm{x}$ & $\mathrm{x}$ & $\mathrm{x}$ \\
\hline 2006-12-04 & $\mathrm{x}$ & & & & $\mathrm{x}$ & & & & \\
\hline \multicolumn{10}{|l|}{ Stn Y31 } \\
\hline Date & $\mathrm{BB}$ & $\mathrm{BP}$ & PB & Pico & PP & MB & $\mathrm{MZ}_{\mathrm{CCR}}$ & Flag & Cil \\
\hline 2006-01-20 & & & $\mathrm{x}$ & & & & & & \\
\hline 2006-03-04 & & & $\mathrm{x}$ & & & & & & \\
\hline 2006-03-15 & & $\mathrm{x}$ & $\mathrm{x}$ & $\mathrm{x}$ & $\mathrm{x}$ & $\mathrm{x}$ & $\mathrm{x}$ & $\mathrm{x}$ & $\mathrm{x}$ \\
\hline 2006-03-29 & & & $\mathrm{x}$ & & $\mathrm{x}$ & & & & \\
\hline 2006-04-05 & & & $\mathrm{x}$ & & $\mathrm{x}$ & & & & \\
\hline 2006-04-11 & & & $\mathrm{x}$ & & $\mathrm{x}$ & & & & \\
\hline 2006-04-19 & $\mathrm{x}$ & $\mathrm{x}$ & $\mathrm{x}$ & & $\mathrm{x}$ & $\mathrm{x}$ & $\mathrm{x}$ & & \\
\hline 2006-04-26 & & & $\mathrm{x}$ & & $\mathrm{x}$ & & & & \\
\hline 2006-05-10 & & & $\mathrm{x}$ & & & & & & \\
\hline 2006-05-23 & & & $\mathrm{x}$ & & & & & & \\
\hline 2006-06-08 & & & $\mathrm{x}$ & & $\mathrm{x}$ & & & & \\
\hline 2006-06-21 & $\mathrm{x}$ & $\mathrm{x}$ & $\mathrm{x}$ & $\mathrm{x}$ & $\mathrm{x}$ & $\mathrm{x}$ & $\mathrm{x}$ & $\mathrm{x}$ & $\mathrm{x}$ \\
\hline 2006-07-05 & $\mathrm{x}$ & $\mathrm{x}$ & $\mathrm{x}$ & $\mathrm{x}$ & $\mathrm{x}$ & $\mathrm{x}$ & $\mathrm{x}$ & $\mathrm{x}$ & $\mathrm{x}$ \\
\hline 2006-07-18 & & & $\mathrm{x}$ & & $\mathrm{x}$ & & & & \\
\hline 2006-08-02 & & & $\mathrm{x}$ & & $\mathrm{x}$ & & & & \\
\hline 2006-08-15 & & & $\mathrm{x}$ & & $\mathrm{x}$ & & & & \\
\hline 2006-08-30 & $\mathrm{x}$ & $\mathrm{x}$ & $\mathrm{x}$ & $\mathrm{x}$ & $\mathrm{x}$ & $\mathrm{x}$ & $\mathrm{x}$ & $\mathrm{x}$ & $\mathrm{x}$ \\
\hline 2006-09-13 & & & $\mathrm{x}$ & & $\mathrm{x}$ & & & & \\
\hline 2006-09-27 & $\mathrm{x}$ & $\mathrm{x}$ & $\mathrm{x}$ & $\mathrm{x}$ & $\mathrm{x}$ & $\mathrm{x}$ & $\mathrm{x}$ & $\mathrm{x}$ & $\mathrm{x}$ \\
\hline 2006-10-11 & $\mathrm{x}$ & $\mathrm{x}$ & $\mathrm{x}$ & $\mathrm{x}$ & $\mathrm{x}$ & $\mathrm{x}$ & $\mathrm{x}$ & $\mathrm{x}$ & $\mathrm{x}$ \\
\hline 2006-11-17 & & & $\mathrm{x}$ & & & & & & \\
\hline Stn H4 & & & & & & & & & \\
\hline Date & $\mathrm{BB}$ & $\mathrm{BP}$ & PB & Pico & PP & $\mathrm{MB}$ & $\mathrm{MZ}_{\mathrm{CCR}}$ & Flag & Cil \\
\hline 2006-01-17 & & & & & $\mathrm{x}$ & & & & \\
\hline 2006-02-14 & & & & & $\mathrm{x}$ & & & & \\
\hline 2006-03-14 & & $\mathrm{x}$ & $\mathrm{x}$ & $\mathrm{x}$ & $\mathrm{x}$ & $\mathrm{x}$ & $\mathrm{x}$ & $\mathrm{x}$ & $\mathrm{x}$ \\
\hline 2006-03-30 & & & & & $\mathrm{x}$ & & & & \\
\hline 2006-04-04 & & & & & $\mathrm{x}$ & & & & \\
\hline 2006-04-10 & & & & & $\mathrm{x}$ & & & & \\
\hline 2006-04-18 & $\mathrm{x}$ & $\mathrm{x}$ & $\mathrm{x}$ & & $\mathrm{x}$ & $\mathrm{x}$ & $\mathrm{x}$ & & $\mathrm{x}$ \\
\hline 2006-04-25 & & & & & $\mathrm{x}$ & & & & \\
\hline 2006-05-09 & & & $\mathrm{x}$ & $\mathrm{x}$ & $\mathrm{x}$ & $\mathrm{x}$ & & $\mathrm{x}$ & $\mathrm{x}$ \\
\hline 2006-05-22 & & & & & $\mathrm{x}$ & & & & \\
\hline 2006-06-07 & & & & & $\mathrm{x}$ & & & & \\
\hline 2006-06-20 & & & & & $\mathrm{x}$ & & & & \\
\hline 2006-07-04 & $\mathrm{x}$ & $\mathrm{x}$ & $\mathrm{x}$ & $\mathrm{x}$ & $\mathrm{x}$ & $\mathrm{x}$ & $\mathrm{x}$ & $\mathrm{x}$ & $\mathrm{x}$ \\
\hline 2006-07-17 & & & & & $\mathrm{x}$ & & & & \\
\hline 2006-08-01 & & & & & $\mathrm{x}$ & & & & \\
\hline 2006-08-17 & & & & & $\mathrm{x}$ & & & & \\
\hline 2006-08-29 & $\mathrm{x}$ & $\mathrm{x}$ & $\mathrm{x}$ & $\mathrm{x}$ & $\mathrm{x}$ & $\mathrm{x}$ & $\mathrm{x}$ & $\mathrm{x}$ & $\mathrm{x}$ \\
\hline 2006-09-12 & & & & & $\mathrm{x}$ & & & & \\
\hline 2006-09-26 & $\mathrm{x}$ & $\mathrm{x}$ & $\mathrm{x}$ & $\mathrm{x}$ & $\mathrm{x}$ & $\mathrm{x}$ & $\mathrm{x}$ & $\mathrm{x}$ & $\mathrm{x}$ \\
\hline 2006-10-10 & & & & & $\mathrm{x}$ & & & & \\
\hline 2006-10-25 & & & & & $\mathrm{x}$ & & & & \\
\hline 2006-11-07 & & & & & $\mathrm{x}$ & & & & \\
\hline 2006-12-18 & & & & & $\mathrm{x}$ & & & & \\
\hline
\end{tabular}

Editorial responsibility: Rodney Forster, Lowestoft, UK
Submitted: January 30, 2010; Accepted: April 9, 2010

Proofs received from author(s): June 4, 2010 